Makale Türü: Araştırma Makalesi

\title{
TARİHÖNCESİNDE SANAT VE BAĞLAMLARI
}

\author{
Yasemin YILMAZ
}

ÖZ

Tarihöncesi sanata dair kalıntılar zengin bir çeşitlilik sunmakta, dünyanın birçok yerinde açı̆̆a çıkarılmakta ve farklı zaman dilimlerine tarihlenmektedir. Makale Üst Paleolitik Dönem'de, Batı Avrupa'da özellikle Fransa ve Íspanya'daki mağaralarda bulunan sanata dair kalıntıları, bunların ekseninde yürütülen tartışmalart ve ileri sürülen hipotezleri değerlendirmektedir. Paleolitik sanat üzerine çalışan bazı araştırmacılara göre, sanatsal üretim insanın olmazsa olmaz özelliklerinden biridir. Bu nedenle, sanatın ortaya çıkışı, Homo sapiens göçü, sembolik düşünce, kültürel modernlik, anatomik modernlik, mit, bilinç gibi kavramlarla örülen bir sistemle ele alınarak, sanatın hangi dinamikler çerçevesinde ve neden üretilmiş olabileceğine dair hipotezler önerilmektedir. Tarihöncesi sanatına dair kalıntılar taşınabilir ve taşınamaz sanat ürünleri olarak sınıflandırılır. Taşınabilir grupta, taş, kemik, diş ve ahşaptan üretilen nesneler ve figürinler yer alır. Bunların gündelik işlerde veya ritüel amaçlı kullanıldı̆̆l düşünülmektedir. Taşınamaz sanat ise mağara, kaya altı sığınă̆ı ve açık havadaki kayalık yüzeylere işlenen gravür, boya ve kabartma teknikleriyle yapılmış betimlemeleri kapsar. İşlenen konular ă̆ırlıklı olarak doğal ortamından ayrıştırlarak betimlenen hayvanlar, antropomorfik figürler, insanlar ve motifler/işaretlerdir.

Anahtar Kelimler: Tarihöncesinde Sanat, Sembolik Düşünce, Kültürel Modernlik, Üst Paleolitik Dönem

\footnotetext{
${ }^{1}$ Dr. Öğr. Üyesi, Düzce Üniversitesi, Fen Edebiyat Fakültesi, Arkeoloji Bölümü, ORCID: 0000-00017258-4920, yaseminyilmaz@duzce.edu.tr
}

Makale Geliş Tarihi: 16 Ekim 2021 Kabul Tarihi: 28 Aralık 2021 


\title{
PREHISTORIC ART AND ITS CONTEXTS
}

\begin{abstract}
Remains of prehistoric art offer a rich variety and are discovered in many parts of the world in different time periods. This article evaluates the Upper Paleolithic remains unearthed in caves in Western Europe, especially in France and Spain, and the discussions and hypotheses about them. According to some researchers working on Paleolithic art, artistic production is one of human beings' sine qua non feature. For this reason, this article discusses the emergence of art in Western Europe within a framework knitted by the concepts of Homo sapiens migration, symbolic thought, cultural modernity, anatomical modernity, myth, and consciousness and seeks answers as to which dynamics may have led to the emergence of art. Remains of prehistoric art are classified as portable and unportable artworks. Portable artworks include objects and figurines made from stone, bone, teeth and wood. It is thought that these objects were used in daily works or for ritual purposes. Unportable artworks, on the other hand, include depictions made with engraving, painting and low relief techniques on rocky surfaces of caves, shelters, and open-air areas. The subjects covered are mainly animals, anthropomorphic figures, humans and motifs/signs, which are depicted by being separated from their natural environment.
\end{abstract}

Keywords: Prehistoric Art, Symbolic thinking, Cultural Modernity, Upper Paleolithic Age. 


\section{Giriş}

Sanat, anlamı, kapsamı, biçimi, içeriği üreten ve "tüketene" göre değişen, tanımlanmaya başladığında karmaşıklaşarak yeni anlamlarla farklı yollar kurmaya kapı açan, dinamik bir kavramdır. Makale, sanat "neden, nerede, ne zaman, niçin, hangi biçimlerde, nasıl ortaya çıkmıştır" sorularını temel alarak, tarihöncesi çağlara ait kalıntılar yoluyla sanatın kökenine ve arkeolojisine odaklanmaktadır. Sanata dair arkeolojik kalıntılar, dünyanın farklı yerlerinde açığa çıkarılmış ve farklı zaman dilimlerine tarihlenmiştir. Özellikle İspanya ve Fransa' da yoğunlaşan Üst Paleolitik dönem mağara duvar sanatı örnekleri üzerinden sanatın kökeni, bağlamı ve toplumsal anlamı hakkında önemli tartışmalar sürdürülmektedir. $\mathrm{Bu}$ tartışmaların ele aldığ1 temel sorular şunlardır: Üst Paleolitik döneme kültürel geçiş, konumuz bağlamında Avrasya coğrafyasında belirli midir? Üst Paleolitik dönem sanatının ortaya çıkışı Homo sapiens'in biyolojik özelliklerinin bir sonucu mudur? Ya da farklı Homo türlerinin kültürel birikimin sonucunda mı ortaya çıkmaktadır? Sanat üretiminde çevresel değişimlerin etkisi var mıdır? Sanatsal üretim, süslenme nesneleri, ölülerin gömülmesi vb. simgesel düşüncenin somutlanması ve modern davranışın birikmesiyle oluşturulan bir sonuç mudur? Üst Paleolitik dönem öncesinde modern davranış veya kültürel modernlik olarak değerlendirilebilecek uygulamalar var midır ve bunlar nelerdir? (Bar-Yosef, 2006, s. 6) Sanatsal üretimin başlangıc1, Homo cinsinin bilişsel süreçlerinin farklılaşması hipotezi; imge, simge, mit, bilinç, Şamanizm, ölü gömme uygulamasının başlangıcı, anlamı, modern insan davranışının ortaya çıkışı gibi birçok kavram ekseninde değerlendirilmektedir (d'Errico ve Stringer, 2011; Gaussein, 2017, s. 36).

Modernlik kavramı, kültürel ve anatomik olmak üzere iki boyutla ele alınmaktadır. Homo sapiens'in anatomik özellikleri ve iskelet sistemine eşlik eden daralmış ve dik yüz, alın kısmının yüksek olması nedeniyle sembollerin beynin bu bölümünde tasarlandığı ve modern düşünme sürecini mümkün kıldığı ileri sürülmekte ve anatomik modernlik olarak adlandırılmaktadır (Lewis-Williams, 2019, 3. Bölüm; Paillet, 2015, s. 91). Kültürel modernlik veya davranışsal modernliğin göstergesi olarak, sembolik öğelerin arkeolojik alanlarda açığa çıkarılmış olması gerekmektedir. Sembolik düşünceye dair arkeolojik kanıtların genel özelliği, hayal gücü ve akılda tasarım gerektiren uygulamalara dair kalıntıların varlığıyla açıklanmaktadır. Davies'e göre (2021), bunlar: boncuklar, takılar gibi süslenme nesneleri, ritüel davranışlar, betimlemeler, ölü gömme uygulamaları ve ölü nesneleri, bakıma ihtiyacı olan bireylerle dayanışma şeklindedir. Kültürel veya davranışsal modernliğin merkezinde yer alan kavram semboldür. Vialou (2009 ) bunu şöyle açıklar,

Bir anlamın belirli bir biçimle/görüntüyle eşleştirilmesine/özdeşleştirilmesine en genel anlamıyla sembol denilmektedir. Sembol, birbirinden bağımsız olan yaratılma zamanını ve kabul edilme/kullanılma süreçlerini bir araya getirmektedir. Bu kapsamda kelimenin 


\begin{abstract}
kökleşmesi, sembolün hikâyesi/tarihi gibidir: Onun görünme sürecini içeren bir geçmiş ve onun anlaşılma süreci için bir gelecek öngörülmelidir. Sembolize etmek ise, anlam çıkarmak veya anlam icat etmek, anlama betim veya grafik olarak bir biçim, bir 'vücut' vermektir. Tarihöncesine ait ikonografik kümelerin göreceli olarak anlam içeriklerindeki tekdüzelik, yerel tekilliklerden kolayca ortaya çıkan sayısız örnek, belirli bir genelliğe ulaşılmasını sağlar. Mağara sanatındaki hayvanlar, başlangıçta doğal biçimler üzerinden sembollerin dikilmesinin/oluşturulmasının ilk örnekleridirler (s. 472).
\end{abstract}

Vialou'nun tanımı ve dikkat çektiği noktalar önemlidir. Sembolik düşünme bir icat ve aynı zamanda kurulan bir "şey" olarak değerlendirilmektedir. Sembollerin kurulması tarihsel bir süreçtir. İnsanlar arasında uzlaşmalar gerektirir. Bu uzlaşımların rastlantısal karşılaşmalardan ziyade düzenli ve süreğen insan ilişkisi gerektirdiği anlamı çıkarılabilir. İkinci olarak biçim-anlam ilişkisi önemlidir. Anlamı temsil edecek biçimlerin yalın, tekrar eden ve işaret ettiği anlam içeriği konusunda tekdüze olması gereklidir. Bir diğer önemli kategori, biçime dönüşen anlamın kendini yeniden üretme sürecidir ki bu imgelerle mümkün hale gelmektedir. İmgenin temel işlevi, hafızayı uyarmaktır, bu nedenledir ki sembolik düşünce, imgelerle hareketlenir. $\mathrm{Bu}$ özellik ise beyinde bilişselliğin ve görsel olarak algılamanın kesişmesinin örtüştüğünün göstergesidir (Fritz ve ark., 2013, s. 39). Mithen, Homo sapiens aklının özelliği olarak değerlendirdiği görsel sembolün iki niteliğine dikkat çeker. İlki, anlam ve anlamı sembolize eden biçim arasında zorunlu doğrusal bir ilişki olmamasıdır. İkincisi, sembol ve temsil ettiği anlam arasında zamansal ve mekânsal bir paralellik aranmamasıdır (Mithen, 1999, ss.181-182). Sembolik düşüncenin ortaya çıkışı, sanatsal üretime başlanmasının ön koşulu değildir. Ancak tarihöncesi sanatın değerlendirilmesi ve kültürel modernlik kavramının anlaşılmasında işlevlidir. Kültürel modernlik kavramının somutlaştırılabilmesi için sembolik düşünceyle birlikte, buluntu toplulukları, bunların üretim sistemleri, kültürel davranış vb. gibi arkeolojik kalıntılarla desteklenen veri setine ihtiyaç duyulmaktadır (Paillet, 2015, s. 91).

Makale tarihöncesi sanatı, arkeolojik yöntemle açığa çıkarılan kalıntılar, üretilen veriler, hipotezler ve yorumlarla ele almaktadır. Bu nedenle ilk bölüm, arkeolojik yönteme ayrılmıştır. İkinci bölüm, sembolik düşünceye dair üretimlerin arkeolojik izleri üzerinden, kültürel modernliğin belirleyici kavramlarından olan sembolün toplumsal iz düşümlerinin anlaşılmasının önünü açacak veriler sunulmaktadır. Üçüncü bölüm tarihöncesi sanatın "arka planına" ayrılmıştır. Üst Paleolitik' in zamansal, mekânsal ve niteliksel verilerine, bu dönemde yaşamış insanların kökeni ve Batı Avrupa'ya gelişleri konusundaki hipotezlere yer verilmiştir. Dördüncü bölümde tarihöncesi sanatın belgelenmesi ve analizler kısaca ele alınmaktadır. Beşinci bölüm, tarihöncesi sanat kalıntılarının kategorik olarak tanıtılmasına ayrılmıştır. Taşınabilir ve taşınamaz sanat, resimlerin yapılış teknikleri olarak gravür, boyama ve heykeltıraşlık. İnsan betimleri, hayvan betimleri, 
motifler/işaretler olarak işlenen konular. Altıncı bölüm, tarihöncesi sanatın anlamı ve işlevi konusunda üretilen hipotezleri sunmaktadır.

\section{Arkeolojik Yöntem}

Arkeoloji, geçmişte yaşamış toplumları, onlardan geriye kalan kalıntılar yoluyla yeniden kurgulama, anlama ve analiz etmenin bilimidir ${ }^{2}$. Eski toplumlardan geriye kalan 'şeylere', zaman, mekân ve doğal ortam bileşenleriyle birlikte odaklanmakta, kalıntıları analiz ederek verilere dönüştürmekte ve elde ettiği sonuçları yorumlayarak eski toplumların geçmişten günümüze varoluş halleri ve değişim dinamiklerini anlamaya çalışmaktadır (Gamble, 2014, s. 2; Özdoğan, 2011, s. 21; Özdoğan, 2019, s. 20). Bir anlamıyla arkeolojik kalıntı, üretilen bilginin belirli düzeylerde sınırlarını oluşturmaktadır. Yüzey araştırması ve kazı eski toplumlardan geriye kalan kalıntılara ulaşmanın genel yöntemlerini, sınıflandırma, karşılaştırma ve ilişsilendirme arkeolojik veri toplamanın temellerini oluşturmakta, disiplinler arası çalışmalarla ${ }^{3}$ ve arkeometrik analizlerden sentezlenen verilerle bütüne, topluma ulaşmaya çalışmaktadır (Özdoğan, 2011, s. 34). Geçmiş denildiğinde hangi zaman diliminden bahsedildiğinin belirlenmesi önemlidir. Arkeolojik kalıntılar göreli ve mutlak yöntemlerle tarihlenmektedir. Makalenin konusunu oluşturan sanat ve bağlamlarının ele aldığı zaman sınırı Prehistoryadır ${ }^{4}$ (tarihöncesi). Tarihöncesinin başlangıc1, tanımlanabilir kültürel nesnelerin üretilmesidir. Bitişi ise genel olarak yazının kullanılmaya başlanmasıdır.

Arkeolojik açıdan kültür edinilen bir olgudur ve insanların bir arada yaşaması etkileşimli öğrenme-öğretme pratiklerini geliştirmesiyle oluşmaktadır. Kültür, kuşaklar arasında aktarılarak, birbirine eklemlenme yoluyla sürekliliği sağlanan somut ve soyut üretimlerin tümünü içerir, kapalı ve izole bir yapı değildir, karmaşıktır ve bu özelliğinden dolayı da dinamiktir (Arsebük, 1995a, s. 19; Gaussein, 2017, s. 37). Günümüze ulaşabilen en eski kültürel nesne standart yontma taş aletlerdir ${ }^{5}$. Standart sözcügü üretilen nesnelerin

\footnotetext{
2 İnsanın temas ettiği her şey arkeolojik kalıntı kategorisindedir. Bir kamp alanındaki kullanım izleri, korunmaya uygun bir alanda kalan ayak izleri, topladıkları, derledikleri tükettikleri bitkiler, avladıkları ya da evcilleştirdikleri hayvanların kemikleri, inşa ettikleri yapılar, delerek boncuk olarak kullandıkları kabuklar, köyler, içinde yaşadıkları ve etkiledikleri peyzaj, anıtsal mezarlar, sanatsal ürünler. Somut olanlar, soyut olanlar, iz bırakanlar ve kimi zaman ise iz bırakmayanlar dâhil olmak üzere kısacası 'öznesinesnesi' insan olan etkilediği ve etkilendiği her şey, arkeolojik kalıntı kategorisindedir (Özdoğan, 2011, s. 39-40; Taşkıran, 2012, s. 171).

3 Günümüzde arkeolojik alanlarda açı̆̆a çıkarılan kalıntılar, Arkeozooloji, Arkeobotanik, Arkeoantropoloji, Arkeojeofizik, antik DNA, izotop analizleri, konumuz bağlamında boyaların bileşen analizleri gibi birçok uzmanlık alanı ile incelenmektedir.

${ }^{4}$ Prehistorya: "Latince; prae-önce ve historia: tarihten türetilmiştir. Prehistorya; 'Insanın insan olma özelliğine kavuşmasından yazının kullanımına değin geçen süreçte, yaşamını ve üretmiş olduğu tüm maddi ve manevi unsurlart inceleyen bilim dalıdir" (Kartal, 2015, s. 150).

${ }^{5}$ Alet: "Hammaddesi veya hammaddeleri doğada bulunan ve doğadaki şekli insan tarafindan şu veya bu şekilde değişstirilmek suretiyle kullanılan şeydir. Aletin ardında değişim ve bu değişime bağlı olarak da yaratıcllk yatar' (Arsebük, 1995b, s. 36). Yontma Taş Alet: “Belirli kirılma özelliklerine sahip kayaçların
} 
rastlantısal olmadığına, ardında "topluluk ya da toplum" barındırdığına, kuşaktaşlar ve kuşaklar arasındaki bir aktarım olduğuna vurgu yapmaktadır (Özdoğan, 2011, s. 21). Standart yontma taş aletler üzerine yapılan teknolojik ${ }^{6}$ ve tipolojik (biçimsel) analizlerle geçmişte yaşamış topluluklar hakkında en erken verilere ulaşılabilmektedir (Baykara ve Dinçer, 2018, s. 316).

\section{Sembolik Düşüncenin Arkeolojik İzleri}

Sembolik düşünceye dair en erken arkeolojik izler Paleolitik Çağ'da ortaya çıkmaktadır. Paleolitik Çăg ${ }^{7}$; Alt Paleolitik (G.Ö. 13.300.000-250.000/200.000); Orta Paleolitik (250.000/200.000-40.000/30.000); Üst Paleolitik (40.000/30.000-10.000) (Bar-Yosef, 2006, s. 4-7; Taşkıran, 2012) olmak üzere üç dönemde incelenmektedir.

Sembolik üretimlere dair en eski izler Alt Paleolitik Dönem'de sınırlı ve az sayıdaki buluntu tipiyle temsil edilmektedir. Alt Paleolitik'e ait kalıntılar ağırlıklı olarak standart yontma taş aletlerdir. 2011 y1lına kadar bu döneme ait en erken tarihler Afrika'da 2.6 milyon yıldı. 2011 yılında Kenya Lomekwi 3'te bulunan taş aletlerle bu dönemin başlangıcı 3.3 milyon yıl öncesine tarihlenmiştir (Harmand ve ark., 2015, s. 310). Sanatın veya soyutlamanın kökeni konusundaki tartışmalarda, ilk sembolik düşünce ipuçları için yontma taş aletlere bakılmaktadır. Alt Paleolitik döneme tarihlenen bazı aletlerin, özellikle biface olarak da adlandırılan iki yüzeyli el baltalarının (Figür 1), geometrik ve simetrik biçimlerinin alete işlevsel bir özellik katmanın yanı sıra, ona estetik bir görünüm kazandırmak, belki de sembolik bir anlam atfetmekle ilişkili olabileceği görüşü ileri sürülmektedir (Le Tensorer, 2006). Renklendirme, nesnelere, giysilere, bedene ölülere farklı bir görünüm katması, tedavi edici olması, kötülüklerden koruma gibi toplumlar ve kültürlerin atfettiği sembolik anlamların üretilmesinde kullanılan bir araç olarak işlevlidir ve Alt Paleolitik Dönem'den itibaren kullanıldığına dair arkeolojik kalıntılar mevcuttur (Kolankaya-Bostanc1, 2012; Özbaşaran, 2019). Alt Paleolitik'e tarihlenen renklendirici maddelerin kazıma, pişirme vb. yollarla bilinçli olarak elde edilmesi ve kullanılmasıyla ilgili en eski izler yaklaşık olarak GÖ 500.000 önceye aittir (Paillet, 2015).

\footnotetext{
üzerinden darbe ya da baskıyla parça çıkararak biçimlendirilen, yani 'yonga' çıkarılarak yapılan aletlere 'yontma taş aletler' denir; çıkarılan parça kadar, üzerinden parça çıkarılan kütle de alet olarak kullanılabilir. Hammaddenin doğadaki haline 'yumru', kopan parçaya 'yonga', üzerinden parça çıkarılan kütleye 'çekirdek', yapılan işleme ise 'yongalama' adı verilir' (Özdoğan, 2019, s. 65).

${ }^{6}$ Teknoloji: “insanın hammadde üzerine yaptı̆̆ işlemlerin tümü için kullanılan genel adlandırmadır. Prehistorik teknoloji; doğadaki çeşitli maddelerin, hammaddelerin; elde edilmesi, dönüştürülmesi, kullanılması ve tüketilmesi süreçlerini içermektedir. Bir grup insanın dolaylı izlerini taşımaktadır" (Karlin ve Pelegrin, 1997, s. 1074).

${ }^{7}$ Buzullaşmalar ve buzul arası dönemlerinin etkisiyle iklim salınımları yoğundur. Buz örtüleri ilerleyipgerilemekte, buna bağlı olarak deniz suyu seviyeleri alçalıp-yükselmektedir. Su seviyeleri düşük olduğunda kıtalar arasında kara köprüleri oluşmakta, sular yükseldiğinde ise kara köprüleri ortadan kalkmaktadır. Bu çağda yeryüzünün değişimi bitki, hayvan ve Homo cinsinin farklı türlerinin ortaya çıkmasında ve yok olmasında etkilidir (Bogucki, 2013, s. 53).
} 


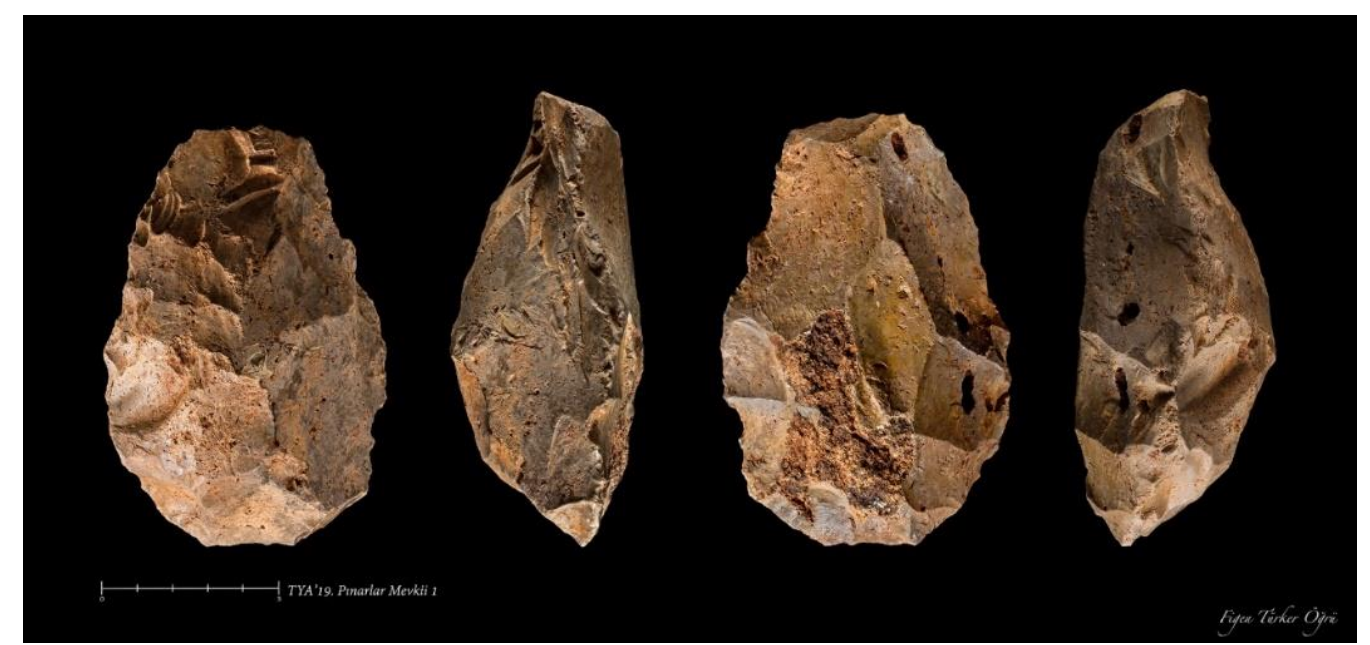

Figür 1.Alt Paleolitik Dönem'e tarihlenen simetrik iki yüzeyli el baltası (Tunceli Yüzey Araştırması Arşivi. Foto: Figen Türker Öğrü).

Orta Paleolitik'le birlikte sembolik anlamla ilişkilendirilen kalıntılarda çeşitlenme ve artış söz konusudur. Avrupa'da Riss-Würm buzul arası ve Würm buzul döneminde geçen bu süreçte (Taşkıran, 2012, s. 184) sert iklim koşullarının olduğu Homo neanderthalensis ve Homo sapiens'in yaşadığı dönemdir. Dönemi simgeleyen Homo neanderthalensis'ler Avrasya'nın önemli bir bölümünde yaşamıştır (Bogucki, 2013, s. 82). Yontma taş endüstrisi Homo neanderthalensis'in kullandığ 1 Moustérien geleneğidir. Avc1-derleyici konar-göçer bir yaşam söz konusudur. Levant Bölgesi'nde yapılan araştırmalarda, Homo neanderthalensis ve Homo sapiens kalıntılarının bulunduğu bölgelerde, aynı hayvan türlerini avladıklarını, Levallois tekniği ile yontma taş alet ürettiklerini ve alet çantalarının da karşılaştırılabilir nitelikte olduğu bildirilmektedir (d'Errico ve Stringer, 2011, s. 1062).

$\mathrm{Bu}$ döneme tarihlenen arkeolojik alanlarda renkli pigmentlere dair farklı bölgelerde çok sayıda kalıntı açığa çıkarılmıştır. Zambiya'da Twin Rivers alanında $260.000-400.000$ yıllarına tarihlenen tabakalarda, üzerlerinde kullanım izleri tespit edilen beş farklı renge ait yaklaşık 200 boya parçası açığa çıkarılmıştır. Afrika'da yaklaşık GÖ 280.000 ve yaklaşık GÖ 160.000'e tarihlenen alanlarda kırmızı pigment kalıntıları bulunmuş olup, pigmentlerin kullanımının yaklaşık GÖ 100.000'e tarihlenen alanlarda yaygınlaştığı belirtilmektedir. Güney Afrika'da Blombos bölgesindeki GÖ 75.000 yıla tarihlenen arkeolojik tabakalarda, üzerlerinde kullanım izleri olan yaklaşı 8.000 hardal parçası açığa çıkarılmıştır. Orta Doğu'da pigmentlerin sistematik kullanımına ilişkin en eski arkeolojik veriler, yaklaşık GÖ 100.000'e tarihlenen Qafzeh ve Skhul'dan bildirilmektedir. Avrupa'daki Homo neanderthallensis'lerin sembolik amaçlarla siyah ve kırmızı pigmentleri yaklaşık GÖ 60.000'lerde sistematik olarak kullandığ belirtilmektedir. Orta Paleolitik ve Erken Üst Paleolitik'e tarihlenen 70'in üzerindeki alanda manganez dioksit ve hardal rengi parçaları bulunmuştur (d'Errico ve Stringer, 
2011, s. 1065; Paillet, 2015, s. 93). Etnografik olarak çok iyi belgelenmiş ve kaydedilmiş pek çok örnek Afrika, Amerika ve Avustralya'da pigmentlerin, az çok uzak veya özel yerlerden getirildiğine, bu karışımların belirli dönemlerde ve belirli törenler eşliğinde hazırlandığına işaret etmektedir (Clottes, 2004).

Bilinçli olarak ölülerin gömülmesi Orta Paleolitik’te Homo neanderthalensis ve Homo sapiens türlerinin ortaklaştığı bir olgudur. Ölünün gömülmesi ve gömülme sürecine eşlik eden ritüellerle, yaşanmış bir deneyimin, bir geçmişin, belirli bir biçimde sabitlenerek gömme eyleminde simgeleştirilmesi, ait olunan grubun yaşayanlarını ve ölülerini içeren uygulamalarla kolektif bir anlam inşa edilme yolu olarak yorumlanmaktadır. Ölü bedenin diğer canlıların ulaşamayacağı belirli bir alana konulması veya toprağın içine açılan çukurlara gömülmesi ölü gömme uygulamasının başlangıcı olarak değerlendirilmektedir (Atakuman vd., 2019, s. 80; Vialou, 2009, s. 467). Ölü gömmeye ritüellerin eşlik ettiğine dair veriler ise ağırlıklı olarak iskeletlerle birlikte bulunan nesneler üzerinden değerlendirilmektedir. Bunlar hayvan kemikleri, kabuklar, kırmızı aşı boyası ve aletlerdir. En eski gömütler, Orta Paleolitik döneme, yaklaşık olarak GÖ 130.000110.000'e tarihlenen İsrail'deki Skhul Mağarası'nda ve GÖ 92.000'e tarihlenen Qafzeh Mağarası'nda açığa çıkarılan Homo sapiens türüne ait kalıntılardır. Skhul V mezarında bulunan yaban domuzu çenesinin bu alana ölü nesnesi olarak konduğu düşünülmektedir (Atakuman ve ark., 2019, s. 80; Pigeaud, 2017, s. 169; Tillier, 2009, s. 55; 117). Yakın Doğu ve Avrupa'da Orta Paleolitik Dönem'e tarihlenen 60 kadar mezardan 35 tanesinin Homo neanderthalensis'lere aittir. Bunlardan ölü nesneleri La Ferrassie, Dordogne'daki Homo neanderthalensis'lere ait gömütlerde saptanmıştır. 8 adet Homo neanderthalensis gömütünden bir erişkinle birlikte taş aletler, üzerinde işlenme izleri olan bir kemik ve oyulmuş bir kaburga bulunmuştur. Yaklaşık üç yaşındaki bir bireyle birlikte ise oyulmuş bir taş açığa çıkarılmıştır (Paillet, 2015).

Sembolik düşüncenin ortaya çıkışının önemli göstergelerinden biri de takılar ya da süslenme nesneleridir (Bar-Yosef Mayer ve Bosch, 2019). Kabuk boncuklarının Homo neanderthalensis'ler tarafından kullanıldığına dair olası kanıtlar, İspanya'nın güneyindeki Cueva de los Aviones'ta MÖ 45.000-50.000 yıllarına tarihlenen Mousterian tabakalarda doğal deliklere sahip üç Acanthocardia ve Glycymeris valfini içeren deniz kabuğu topluluğu ile temsil edilmektedir. Homo neanderthalensis'lerin yaklaşık 38.000 ila 32.000 yıl önce kemik veya fildişi kolyeler, delinmiş ve yivli hayvan dişleri, delinmiş taşlar ve delinmiş deniz kabuklarından süslenme nesneleri/takılar ürettikleri arkeolojik alanlardan saptanmıştır. Özellikle Fransa Yonne Arcy-sur-Cure'deki Ren Geyiği Mağarası'nın Châtelperronian katmanlarında süslenme eşyaları/takılara ait kalıntılar açığa çıkarılmıştır (d'Errico ve Stringer, 2011, s. 1066; Taborin, 1998). Güney Afrika'da Blombos Mağaras1, Sibidu ve Border Mağaralarında; Fas'ta Bizmoune, Contrebandier Mağarası, Smugglers Mağaras1, El Mnasra, El Harhoura, Dar es Soltan, İfri n'Ammar, Taforalt, Pigeons Mğarası, Rfafats, Qued Djebbana, Etiyopya'da Porc-Epic, İsrail'de Skhul ve Qafzeh'de 
Orta Paleolitik'e tarihlenen boncuklar açığa çıkarılmıştır (Steele ve ark., 2019, Tablo 1). Blombos ve Sibudu mağaralarında bulunan deniz kabuklarının yine takı vb. gibi kullanıldığı ve bunların GÖ 75.000-70.000'e tarihlendiği bildirilmektedir. Blombos'da açığa çıkarılan 41 adet delinmiş deniz kabuğunun bazılarının üzerinde aşı boyası da saptanmış olması bunların süslenme nesnesi olarak kullanıldı̆̆ının göstergesi olarak değerlendirilmektedir (Steele ve ark., 2019). İsrail'deki Skhul ve Qafzeh Mağaralarında deniz kabuklarından üretilen boncuklar 135.000-130.000'e tarihlenmektedir. Qafzeh'de bulunan boncukta da aşı boyası izleri saptanmıştır (Bar-Yosef ve ark., 2009). Hatay ilinde yer alan Üçağızlı II Mağarası'nda Orta Paleolitik dönem tabakalarında (en alt evre GÖ 75.000- en üst evre 42.000) deniz kabuğunun (Columbella rustica) bilinçli olarak kesilerek delinmesiyle üretilen iki adet boncuk, bu dönemde Doğu Akdeniz'deki takılara ait en erken bulgu olarak değerlendirilmektedir (Baykara ve ark., 2021).

Son yıllarda yapılan keşifler ve bunlar üzerine yapılan analiz çalışmalarında, mağara duvarlarına veya kaya yüzlerine farklı betimlerin Orta Paleolitik'te Homo neanderthalensis'ler tarafından yapıldığına dair kalıntılar olduğu bildirilmektedir. İspanya'da İberya Yarımadası'nda La Pasiega, Maltravieso ve Ardalas'taki duvar resimlerinin mutlak tarihleme yöntemleriyle GÖ 64.800'e tarihlendiği ve bunların Homo neanderthalensis'ler tarafından yapıldığı düşünülmekte (Hoffmann ve ark., 2018) ve bu sonuçlara karşıt argümanlar ileri sürülmektedir (White ve ark., 2019).

\section{Tarihöncesi Sanat ve Üst Paleolitik Dönem}

Avrupa'da Üst Paleolitik'in alt kültürel dönemleri: Chatelperronien (35.000-30.000 BP); Aurignacien (35.000-29.000 BP); Gravettien (29.000-22.000 BP); Solutréen (22.00019.000 BP); Magdalenien (GÖ 19.000-12.000) (Figür 1) ${ }^{8}$. Üst Paleolitik Dönem insanları açık hava alanları, kaya altı sığınakları, mağaralarda yaşamışlardır. Avcı-derleyici toplulukların, genellikle birkaç bin $\mathrm{km}^{2} \mathrm{ye}$ varan geniş bir çevrede, iklimin ${ }^{9} \mathrm{ve}$

\footnotetext{
${ }^{8}$ Aurignacien, Gravettien, Solutreen, Magdalenien dönemlerinde kültürel olarak birbirine yakın yaşam tarzları olmakla birlikte belirli ayrımlar da söz konusudur. Bunlar, yontma taş ve kemik aletlerdeki tipolojik farklılıklardır. Aurignacien'den Magdelenien'e uzanan süreçte, kullanılan alanların sayısal olarak yoğun artış göstermesi, bu durumun demografideki bir çoğalmaya denk geldiği belirtilmektedir.

${ }^{9}$ Üst Paleolitik kültürler iklimsel olarak son Buzul Dönemi’nin (Würm Buzul Dönemi) II. evresinde yaşanmıştır (Leroi-Gourhan, 1983, s. 102; Özçelik, 2015, s. 124; Taşkıran, 2012, s.186). Würm içinde; buzul (stadial) ve buzul arası (interstadial) olarak adlandırılan dönemler söz konusudur. Würm buzullaşmasının Würm I (günümüzden 110.000 yıl önce başlamış) ve Würm II (günümüzden 30.000 yıl önce başlamış) olmak üzere iki önemli aşama içerdiği belirtilmektedir. Buzulların GÖ 30.000'lerde etkin olmaya başladığı, özellikle 21.000-17.000 yılları arasında, kurak ve soğuk iklimin egemen olduğu, bitki örtüsünde ormanlık alanların azaldığı, iklimdeki değişimlerin etkisiyle GÖ 35.000-22.000 arasında volkanizma hareketliklerinin arttığına dikkat çekilmektedir. Buzullaşmaların etkisiyle; günümüz deniz seviyelerinin 130 m alçalması sonucunda 'geniş kıyısal ovaların' ortaya çıktığı, canlı yaşamının bu alanlara kaydığı ve insanların da bu bölgelerde ya da kıyı kesimine yakın mağaralarda yaşadığı düşünülmektedir (Özçelik, 2015, ss. 124-125).
} 
kaynakların durumuyla belirlenen mevsimsel bir döngüye göre tekrarlayan rotalarda konar-göçer yaşam biçimini sürdürdükleri, bu geniş çevrenin ovalık, dağlık gibi farklı ekolojik ve coğrafi alanlar içerdiği belirtilmektedir. Kazılarda bulunan hayvan kemiklerinin arkeozoolojik analiz sonuçları bu durumu desteklemektedir (Bracco ve Montoya, 2015, s. 75, 78, 81; Sauvet, 2019). Sanatın ortaya çıkış1 ve kökeni üzerine yürütülen tartışmalar, Orta Paleolitik ve Üst Paleolitik arasındaki farklılıklar ve benzerliklerle birlikte ele alınmaktadır. Orta Paleolitik’ten, Üst Paleolitik’e geçişe dair arkeolojik kalıntılar Kuzey İspanya ve Güneybatı Fransa'da yoğunlaşmakta ve bu bölgede GÖ 45.000-35.000 y1l önceye tarihlenmektedir (Lewis-Williams, 2019, s. 70).

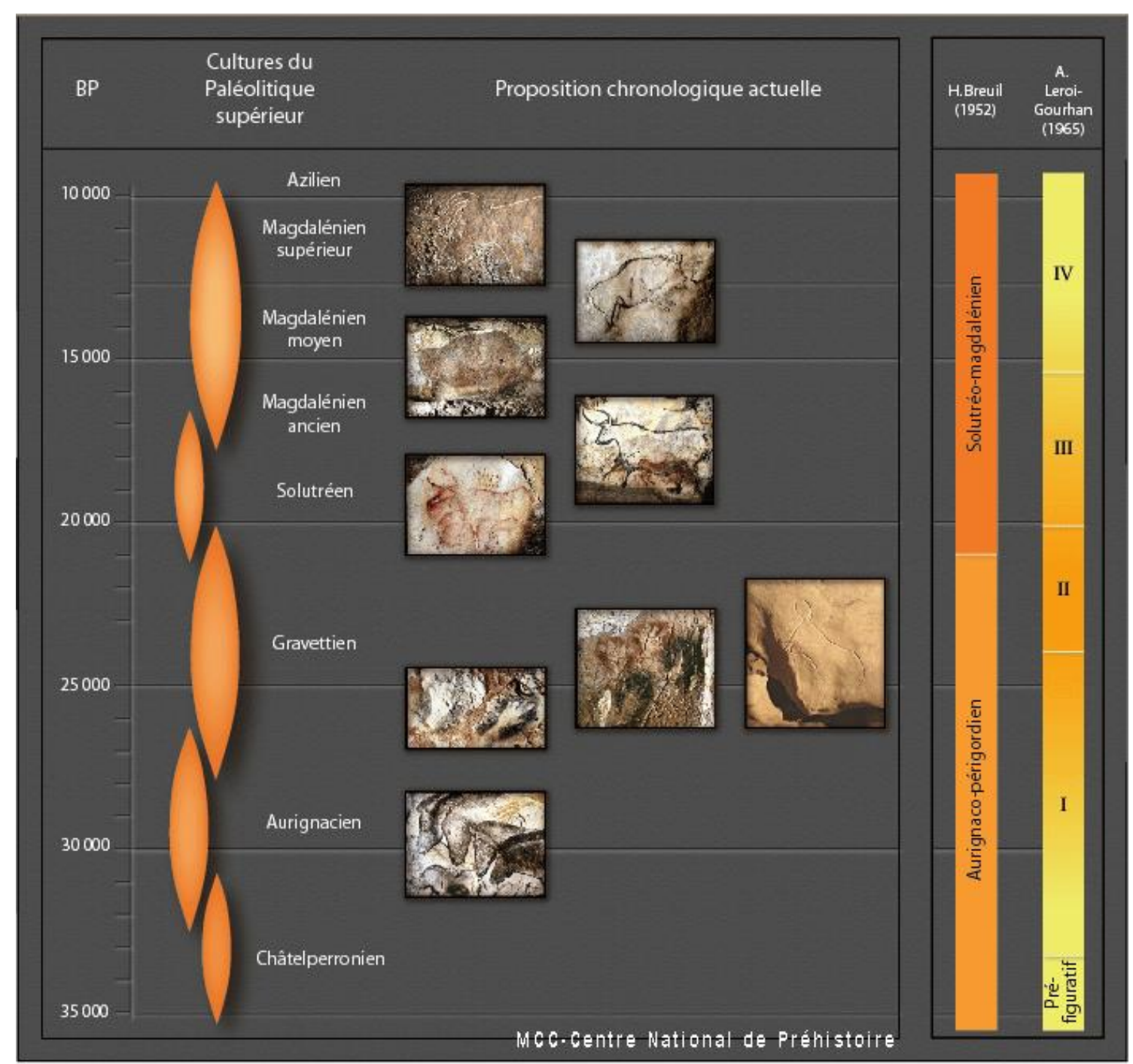

Figür 2. Avrupa Üst Paleolitik Kültürlerin kronolojisi, Tarihöncesi Sanatın Göreli Kronolojisinde H.Breuil ve A.Leroi-Gourhan'ın önerilerinin karşılaştırmalı tablosu (Ministère de la Culture, 2021). 
Batı Avrupa'da Orta Paleolitik'in bitişi ve Üst Paleolitik'in başlangıcı, başka bir ifadeyle kültürel modernlik kavramının sınırları arkeolojik kalıntılar temel alınarak belirlenmektedir. Bunlardan ilki yontma taş alet endüstrisidir. Orta Paleolitik'te baskın olan yonga endüstrisi yerini Üst Paleolitik’te dilgi endüstrisine bırakmıştır. Dilgi ${ }^{10}$ ve dilgicik üretimi Orta Paleolitik'te (yaklaşık GÖ 130.000'lerde) başlamakta; Üst Paleolitik boyunca alet çantasının yaygın ve temel formu olma özelliği göstermektedir. Uzun ve düzenli dilgiler elde edilebilmesi için özel bir yongalama tekniği kullanılması, bunlar, 'uzmanlaşmış ustaların üretimi olabilir mi' sorusunu akla getirmektedir (Arsebük, 1995b, s. XIV; Bar-Yosef, 2006, ss. 6-8; Bracco ve Montoya, 2015, s. 76; Paillet, 2015, s. 91). Dönemi simgeleyen ikinci öğe, hayvanların boynuz, diş, fildişi, kabuk gibi dayanıklı kısımlarının hammadde olarak kullanılmasıyla birlikte ortaya çıkan kemik endüstrisidir. Üst Paleolitik öncesinde de hayvan kemiklerinin alet yapımında kullanıldığına dair az sayıda arkeolojik kalıntı bulunmakla birlikte, bu dönemde kemiğin kullanımı yoğunlaşmış ve işlenmesine yönelik özel teknikler geliştirilmiştir. Kemikten, uçlar, mızrak, zıpkın başı; hayvan derilerinin işlenmesi için kullanıldığı düşünülen açkı aletleri, iğneler, bızlar, ritüel nesneleri ve sanat eserlerinin üretiminde kullanılmıştır (Bar-Yosef, 2006, ss. 8-9; Bracco ve Montoya, 2015, ss. 76-77; Leroi-Gourhan, 1983, ss. 110-112; Lewis-Williams, 2019, s. 76). Üst Paleolitik'te uzak mesafeler arasındaki hammadde ve prestij nesnelerinin değişimi söz konusudur. Özellikle üretilen nesnelerin sadece topluluğun içsel ihtiyaçları ile sınırlanmadığı başka topluluklarla armağan, takas gibi ilişkilenme biçimleriyle farklı bölgelerdeki gruplar arasında bağlantılar pekiştirildiği, bilgi aktarımları yapıldığı, farklı coğrafi ortamları tanıma ve çeşitlenmiş kaynaklara ulaşma olasılı̆̆ı belirmektedir. Bu süreçlerin aynı zamanda toplulukların bağ kurma, düşünme ve duygu dünyasında karmaşıklaşmayı beraberinde getirdiği de ileri sürülmektedir. Dönem ayrıca, sembolik yapının kurulması ve buna eşlik eden uygulamalar olarak ritüeller, aşı boyasının yaygınlaşan kullanımı, ölü gömme uygulamalarındaki çeşitlenme, takılar, taşınabilir ve taşınamaz sanat kalıntılarının yoğunlaşmasıyla özellik kazanmaktadır (Kolankaya-Bostanc1, 2019; Paillet, 2015, ss. 91 92; Sauvet, 2019). Üst Paleolitik’te, avcılık için çok daha etkili aletler; uçlu mızraklar ya da biraz daha geç bir dönemde yaylar, oklar ve bumeranglar icat edilmiş ve böylece hayvanları uzaktan avlamak mümkün hale gelmiştir. Gündelik hayatın geçtiği yerlerde açığa çıkarılan izler bu dönemde yaşam alanlarında biçimlendirilerek oluşturulmuş ocakların sıklıkla kullanıldığını göstermektedir. Ayrıca yaşam için, yemek pişirmek için, kesim için, depolama ve avlanma alanı olarak kullanılan yerlerin işlevlerine göre organize

\footnotetext{
${ }^{10}$ Dilgi: Boyu eninin iki katı veya daha fazla olan aletlere verilen addır. Ağırlıklı olarak çakmaktaşından üretilen dilgi ve dilgicikler doğrudan alet olarak kullanılabildiği gibi, ihtiyaca göre; kazıyıcı, delici, kalem ve ok ucu gibi aletlerin üretiminin ön formu olarak da işlev görmektedir.
} 
edilmesi, Üst Paleolitik kullanım alanlarında görülen ortak bir uygulamadır (Bar-Yosef, 2006, ss. 8-10).

Üst Paleolitik'te özellikle Avrupa'da ortaya çıkan “yenilikler”, bazı araştırmacılar tarafından "yaratıcı devrim veya yaratım devrimi”" olarak ele alınmaktadır. Bu hipotez, sanatın ortaya çıkışının insanın bilişsel olarak dünyayı, kendisini, özellikle de hayvanları farklı biçimde algıladığı ve onlara farklı sembolik anlamlar yüklediği fikri üzerinden şekillenmektedir. "Üst Paleolitik devrimsel bir niteliğe denk gelmekte midir?” sorusunu değerlendiren hipotezler, Orta Paleolitik'in çok daha uzun bir zaman dilimine denk geldiğini ve bu süreçte "yeniliklerin” yavaş bir değişimin sonucunda ortaya çıktığ 1 görüşünü ileri sürmektedir. Buna karşın Üst Paleolitik’te, özellikle Kuzey Afrika, Avrupa, Kuzey ve Batı Asya'da arkeolojik kalıntılardan elde edilen veriler teknolojik, kültürel, gündelik yaşam, uzak mesafelerle süreğen ilişkiler açısından hızlı değişimler olduğuna ve bu duruma nüfusta bir artışın da eşlik ettiğine dikkat çekmektedir (BarYosef, 2006, s.7, 16).

Üst Paleolitik Dönem'de, modern insan dünyaya yayılarak etkin tür haline gelmektedir. Modern insanın kökeni ve yayılımı hakkında farklı hipotezler ileri sürülmektedir. Bunlardan ilki 60.000 ve 40.000 yıl önce modern insanların Afrika'dan 2. kez çıktıkları ve kuzeye yayılarak ulaştıkları bölgelerdeki türlerin yerini aldığı görüşüdür ve «Out of Africa/Afrika Dışına Çıkış ya da Yerini Alma» hipotezi olarak adlandırılmaktadır (BarYosef, 2006, s. 20; Savaş Güleç, 2016, s. 43). İkincisi 'çok bölgeli evrim modeli'dir. Modern insanın kökeninin tek bir bölge ya da tek bir grup olmadığ1, toplulukların birbiriyle karşılaşması ve karışmasıyla oluştuğu ileri sürülmekte ve Afrika'dan kuzeye doğru bir göçten bahsedilmemektedir (Savaş Güleç, 2016, s. 43). C 14 tarihleri Üst Paleolitik Dönem'in dünyanın farklı bölgelerinde farklı tarihlerde yaşandığını göstermektedir. Afrika dışındaki en eski kalıntılar Levant Bölgesi'nden bilinmektedir. Buna göre Levant Bölgesi'nde Üst Paleolitik'in başlangıc1 47.000-45.000 y1l öncesine kadar gitmekte ve ilk hipoteze göre, Avrupa Üst Paleolitik Kültürü'nü oluşturan insanların, GÖ 45.000/43.000/38.000 tarihlerinde Avrupa'ya göç ettikleri ileri sürülmektedir (Bar-Yosef, 2006, s. 18).

Üst Paleolitik ile birlikte yaygın ve görünür olan, kültürel modernlik olarak nitelenen özellikler 'nerede, ne zaman ve hangi dinamiklerle ortaya çıkmıştır' sorularına yanıt olarak hipotezler önerilmektedir. Bu hipotezlerden ilki Üst Paleolitik'e geçişi, dünya çapında evrensel bir durum olarak değerlendirmekte ve Doğu Avrupa'nın bir yerlerinden Batı Asya ve Avrupa'ya göç eden modern insanların getirdikleri bir olgu olarak yorumlamaktadır (Bar-Yosef, 2006, s. 6). İkinci hipotez, Üst Paleolitik dönemin başlangıcında GÖ 40.000'lere doğru anatomik olarak ilk modern insanların Avrupa'ya (Homo sapiens ya da Cro-Magnon) gelmesiyle birlikte 'kültürel patlama-big bang culturel' yaşandığını ileri sürmektedir. Bu durumun kanıtı olarak da sembolik anlamlar içeren tarihöncesi sanatı üretmiş olmaları gösterilmektedir. Diğer hipotez, sembolik 
düşüncenin göstergesi olan üretimlerin, Afrika'da Orta Paleolitik'te GÖ 200.00020.000'de Homo sapiens'lerde meydana gelen biyolojik bir mutasyonun doğrudan sonucu olarak ortaya çıtı̆̆ 1 ve süreç içerisinde Avrasya'ya doğru yayılmış olabileceği görüşüdür. Kültürel patlama ve Homo sapiens'te ortaya çıkan mutasyon hipotezlerinin arkeolojik verilerle tam olarak örtüşmediğine dikkat çekilmektedir (Lewis-Williams, 2019, ss. 80-81; Paillet, 2015, s. 92). Hipotezlerden bir diğeri ise, beynin işleyişindeki bir genetik mutasyonun ana etken olduğunu ve modern özelliklerin yayılmasını tetikleyen bu mutasyonun Afrika'da GÖ 50.000 yıl önce oluştuğunu ileri sürmektedir. Bazı araştırmacılar ise bu nörolojik farklılaşmanın GÖ 60.000-80.000 öncesinde Güney Afrika'daki kültürel yeniliklerle ilişkili olduğu görüşünü benimsemektedir (d'Errico ve Stringer, 2011, s. 1060). Kültürdeki bu farklılaşmanın aklın yeniden örgütlenmesinin bir sonucu olduğunu ileri süren varsayımlar da söz konusudur (Mithen 1999, s. 177). Tarihöncesi sanatın kökeni ve evrimi üzerine çalışan araştırmacıların bir bölümü, modernlik kavramının sapiens türünün fizyolojik özellikleriyle desteklenen ayırt edici niteliklerinden biri olduğu görüşünü savunmaktadır (Sauvet ve Wlodarczyk, 2001, s. 218). İkinci grup ise sanatsal üretimin başlangıcını fizyolojik/anatomik bir altyapı ile doğrudan ilişkilendirmenin arkeolojik kalıntılarla çeliştiğini ileri sürmektedir. Kültürel modernlik veya davranışsal modernlik olarak adlandırılan özelliklerin Homo cinsinin farklı türleri tarafından uzun süreçte icra edilmiş ve dünyanın farklı bölgelerinde farklı zaman dilimlerinde ortaya çıkmış bir kavram olarak ele alınmasını önermektedir. Son keşifler, modern özelliklerin ortaya çıkma süreci ve ne tür arkeolojik kalıntıların bu kategoride kabul edilebileceği konusunda yeni veriler sunmaktadır. Güney Afrika'da Blombos Mağarası'nda açığa çıkarılan ve yaklaşık GÖ 75.000'e tarihlenen kalıntılar, özellikle bir taş üzerindeki çizgisel bezemeler ve üzeri delinmiş çok sayıda kabuk, eski hipotezlerin gözden geçirilerek yeni hipotezlerin üretilmesi gerektiğini ortaya koymuştur. Bu keşifler sembolik düşünmenin Avrupa'da birdenbire ortaya çıkıp saçılan bir olgu olmadığını, sembolik düşünme yeteneğinin gelişiminin daha uzun bir sürece yayıldığını düşündürmektedir. Sembolik düşünme özelliğinin Homo sapiens türünün ayırt edici özelliği olmadığına dair kalıntılar da artmaktadır. Son yıllarda sembolik düşüncenin farklı coğrafi bölgelerde (Afrika, Yakın Doğu, Avrupa) Üst Paleolitik’ten önce yaşamış Homo cinsinin farklı türlerinde ve uzun bir sürece yayılarak kademeli bir biçimde ortaya çıktığ 1 görüşü, biyolojiyle kültürün eşleştirilmesine dayanan hipotezleri reddetmiştir (d'Errico ve Stringer, 2011; Davies, 2021; Paillet, 2015). Sapiens'in ürettiği kültürün karmaşık yapısının onun biyolojik yapısıyla açıklanamayacağına, bu durumun sosyal organizasyonuyla bağlantılı olduğuna dikkat çeken bir başka bakış açısı daha söz konusudur (Condemi ve Savatier, 2018, s. 82-83). 


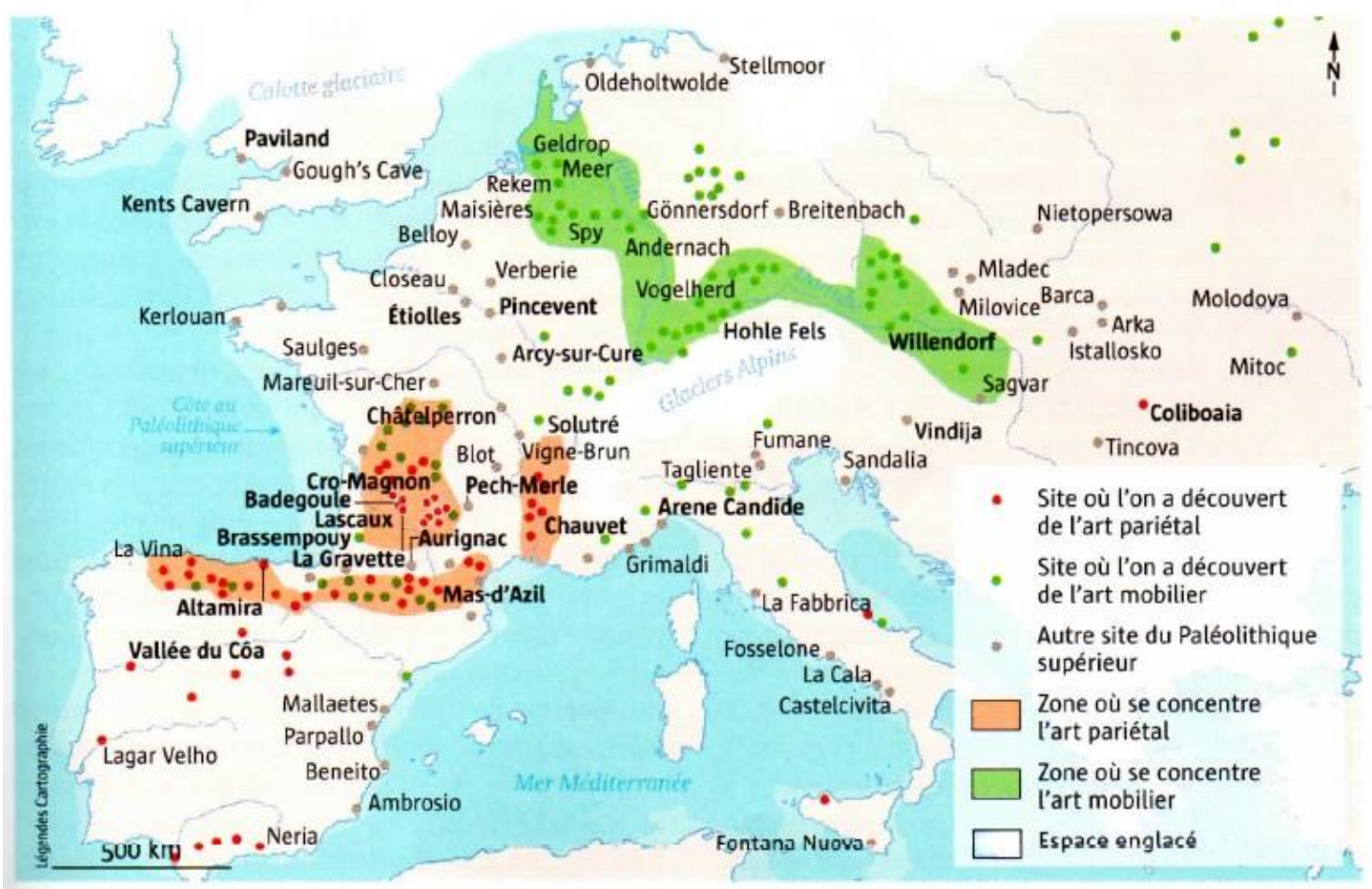

Figür 3. Tarihöncesi sanata dair farklı bölgelerde bulunan arkeolojik kalıntıların dağılımı (Mar, D. 2021).

\section{Tarihöncesi Sanat: Belgeleme, Tarihleme ve Boyaların Analizi}

Arkeolojik kalıntılar genel olarak, doğanın ve kimi zaman da insanların etkisine açık alanlarda binlerce yıl kaldıktan sonra bozulmuş, parçalanmış olarak açığa çıkarılmakta ve birçok teknikle belgelenerek, ayrıştırılarak, birleştirilerek, ilişkilendirilerek nitelikleri belirlenmektedir. Tarihöncesi sanat kalıntıları da erozyon, nem, doğa ve insan etkisiyle bozulmaktadır. Kaya üzerine çizilen çizgiler zamanla tahribata uğrayarak belirsizleşmekte, boyaların dökülmesi sonucunda betimlerin eksik kalmış kısımları özel 1şıklandırmalarla izleri takip edilip tamamlanarak belgelenmektedir. Kalıntıların analizleriyle resimlerdeki öncelik-sonralık ilişkisi, yapım tekniği, kullanılan malzemeler, aletler belirlenmektedir. Mağara sanatı ya da kaya sanatı üzerine yapılan çalışmaların ilk etabı rölövelerinin alınmasıdır. Rölöveler için çizim, haritalama, fotoğraf, 3 boyutlu tarayıcılar birlikte kullanılmaktadır. Tek tek figürlerin, şekillerin yanı sıra rölöveler, resimlerin bulunduğu alanın genel organizasyonu, mağara duvarlarının özelliklerini, galerilerin biçimlerini de kayıt altına almaktadır. Fotoğraf, arkeolojik kalıntıların belgelenmesinde kullanılan temel tekniklerdendir. Özellikle dijital fotoğraflamayla birlikte, fotoğraf ve rölöve iç içe geçmiştir. Günümüzde resim olan duvarlara dokunulmaksızın o alanlar, farklı renk tonlarını ortaya çıkaran filtreler, kontrastların arttırılması, 1şık radyasyonu analizi, fotogrametri vb. birçok teknik kullanılarak resimler belgelenmektedir. Bir sonraki aşamada fotoğraflardan yola çıkarak son dönem 
teknolojilerinin sunduğu olanaklarla resimler, panolar üç boyutlu hale getirilerek sanal olarak yeniden oluşturulmaktadır. Bu yöntemle, panoda yer alan gravür, siyah veya kırmızı boyayla yapılmış resimler, doğal tahribatlar, kabartmalar gibi aynı yüzeyde bir arada bulunan farkl1lıklar birbirinden sanal olarak ayrılarak incelenmektedir. Örneğin sadece siyah resimler görülmek istendiğinde diğer her şey kapatılabilmekte, üst üste olan resimlerde farklı dönemler ele alınabilmektedir. Son teknolojilerle bir alanın rölövesinin alınması araştırmacının alana derinlemesine vâkıf olmasını, en belirsiz izlerin görünür kılınmasını, bazı durumlarda yok olan bir figürün yeniden oluşturulmasını mümkün k1lmaktadır (Feruglio ve Robert, 2015; Fuentes ve ark., 2019; Paillet, 2015, s. 87-89).

Paleolitik sanat kalıntılarının ait olduğu dönemin belirlenmesinde göreli ve mutlak tarihleme yöntemleri kullanılmaktadır. Keşfedilen tarihöncesi sanat kalıntılarının 'eski' olduğu kabul edildikten sonra 20 yy'ın başlarından itibaren Henri Breuil'in önerdiği resimlerin veya gravürlerin üst üste bindirilmesinin incelenmesiyle oluşturulan göreli tarihleme yöntemi kullanılmıştır (Paillet, 2015, s. 88). A. Leroi-Gourhan (1965) tarafından, resimlerin yapım teknikleri dikkate alınarak oluşturulan stil kronolojisi 1980’lere kadar Avrupa tarihöncesi sanat kalıntılarının göreli tarihlenmesinde yaygın olarak kullanılmıştır. Açığa çıkarılan gravür, resim ve heykeltıraşlık eserleri sınıflandırılarak dönemlerin özellikleri tanımlanmış ve 5 farklı stilistik ayrım oluşturulmuştur (Figür 4). Bunlar,

Figüratif Öncesi Dönem: Bu dönemde henüz belirli bir anlam ifade eden hiçbir figür bulunmuyor.

İlksel Dönem (Stil I ve II): Stil I, tartışmaya yer olmaksızın gravür ya da boyamalarla kalker plakaların üzerine figürlerin yapıldığı dönem. Stil II, Gravetien boyunca ve Solutrien'de yavaş yavaş Stil I'den farklılaşmaktadır. Stil II'de hayvan figürleri kabataslak/yalın biçimde betimlenmekte, bizon, at, mamut, dağkeçisinin ayırt edici detayları nüanslarla gösterilmektedir. İnsan betimlerinde gövde kısmı öne çıkarılmış kafatası ve uzuvlara oranla çok daha büyük ve "steatopy"dir. Parietal döneme tarihlenen en eski resimler bu döneme aittir.

Arkaik Dönem (Stil III): Boyama, heykeltıraşl1k ve gravür tekniklerinin çok iyi uygulandığı bir dönem. Hayvan betimlerinde büyük bir gövde, buna karşın kafa ve uzuvlar küçüktür. İnsan figürlerinde de aynı betimleme prensibi görülmektedir. Gövdelerin büyüklüğü hamile hayvanların betimlendiğini düşündürmüş olmakla birlikte betimlenen hayvanlar ağırlıklı olarak erkektir. Bu durum Stil III'e özgüdür. Style III'ün hayvan formları başlangıç ve sonda belirgin bir evrim göstermektedir.

Klasik Dönem (Stil IV): Hayvanlar daha gerçekçi resmedilmekte, doğal vücut oranlarıyla kıl vb. gibi detaylara yer verilmektedir. Bununla birlikte figürler askıda gibi, uzuvlar sarkmış, sadece uç kısımlar yere değer gibidir. Heykelcikler ve mağara sanatındaki insan 
figürleri sadece gövdeyle sınırlandırılmıştır. Baş, göğüs, kollar olmaksızın profilden çizilmişlerdir.

Geç Dönem (Stil IV son): Mağara sanatı artık durmuş gibidir ve ağırlıklı olarak taşınabilir sanat öğeleri artmıştır. Hayvanlar biçim ve hareket açısından daha gerçekçidir (LeroiGourhan, 1990, 87-90).

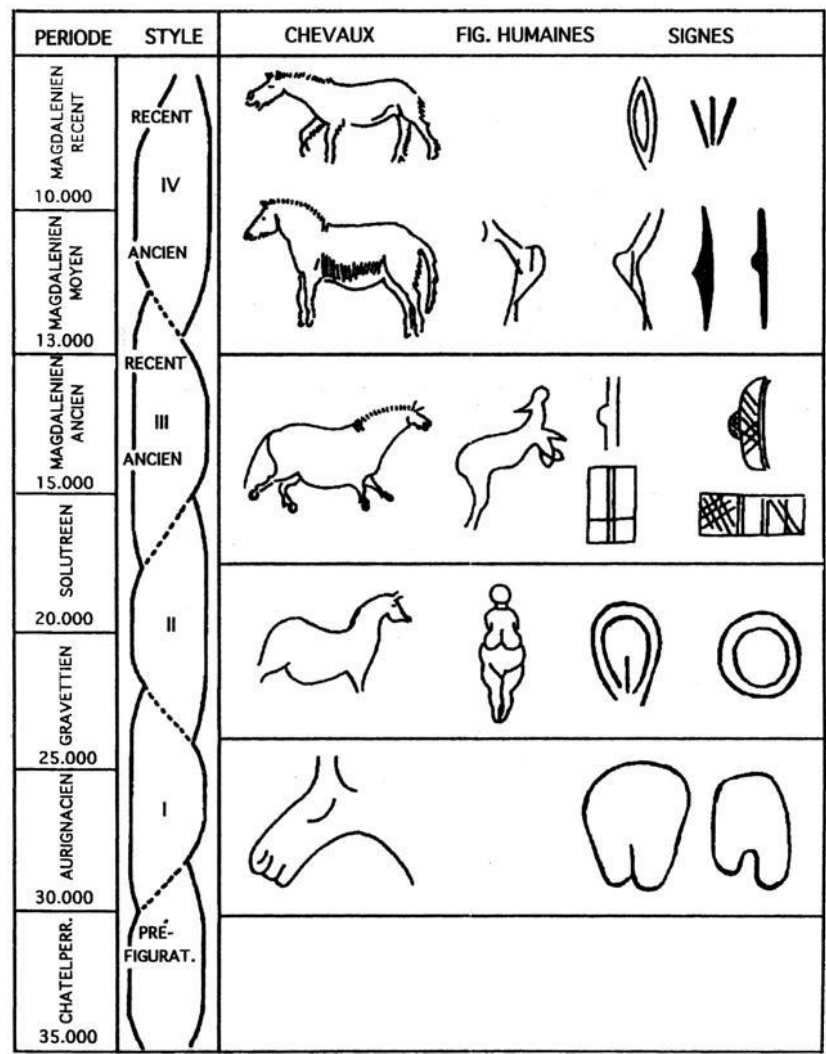

Figür 4. Leroi-Gourhan tarafından, resimlerin yapılma teknikleri dikkate alınarak oluşturulan stil kronolojisi (Leroi-Gourhan, 1990, s. 88, figür 6).

Tarihöncesi sanat kalıntılarının radyometrik yöntemlerle tarihlenmeye ${ }^{11}$ başlanmasıyla birlikte, A. Leroi-Gourhan'1n göreli kronolojisinin bütünüyle geçerli olmadığ 1 ortaya çıkmış ve yoğun olarak eleştirilmiştir. Bununla birlikte Leroi-Gourhan'ın düşüncelerinin etkileri devam etmektedir (Feruglio ve Robert, 2015; Garate-Maidagan ve Moro-Abadia, 2012). Tarihöncesi sanat kalıntılarının doğrudan tarihlenmesi için kullanılan kesin tarihleme yöntemlerinden birisi ${ }^{14} \mathrm{C}$ 'tür. Bu yöntem için, kömür, kemik, bitki kalıntısı gibi

\footnotetext{
${ }^{11}$ Tarihöncesi sanatın tarihlenmesinde kullanılan radyometrik ölçümlerin toplu bir değerlendirmesi için bk. Sauvet, G. (2015). A la recherche de Temps Perdu. Methodes de Datations en Art Prehistorique.

l'exemple des sites aurignaciens. Aurignacian Genius art, technologie et société des premiers hommes modernes en Europe, P@lethnologie, 210-225.
} 
organik maddelere ihtiyaç duyulmaktadır. 1994 yılında keşfedilen Chauvet-Pont d'Arc Mağarası'nın duvarlarındaki resimlerin bir bölümünde siyah renk için yakılmış ahşap kullanılmıştır. Bu yöntemle doğrudan resimlerden alınan karbon örneklerinden 1995 'te ${ }^{14} \mathrm{C}$ tarihlemesi yapılmıştır. Chauvet-Pont d'Arc Mağarası'ndaki resim yapma tekniğindeki ustalık, Paleolitik sanatın dönüm noktalarından biri olarak değerlendirilmektedir. Chauvet'in keşfi ve tarihi, tarihöncesi sanatın ve sembolik düşüncenin gelişimi konusundaki çizgisel modeli temelden sarsmıştır. 2014'e kadar mağarada 150 'den fazla ${ }^{14} \mathrm{C}$ tarihlemesi yapıldı $\breve{g}_{1}$ bildirilmektedir (Fritz ve Tosello, 2015, Valladas ve ark., 2005). Bu analizlerin sonuçlarına göre mağaranın Aurignacian'de (GÖ. 37,000-36,200 ila 34,400-33,500'e) ve Gravettian'de (GÖ 31,400-30,700 ila 29,70027,900) kullanılmış olduğu belirlenmiştir (Salmon ve ark, 2021). Resimlerden alınan örneklerle doğrudan mutlak tarihleme yapılamadığı durumlarda tarihöncesi sanat kalıntıları eğer tanımlı kronolojik tabakalarla ilişkilendirilebilirse kronolojik sürece bağlanabilmektedir.

Raman spektroskopisi, küçük miktarlarda malzeme üzerinde X-ışını mikro analizi, SEM veya hızlandırıcı ile element analizi, difraktometri, faz kromatografisi, gaz ve optik analizlerle tarihöncesi sanat incelenmektedir. $\mathrm{Bu}$ analizlerle, renklendirici olarak kullanılmış hammaddeler, boya yapımında kullanılan bağlayıcılar, katkılar, dolgu maddelerinin ve eser minerallerinin niteliği ve bazı durumlarda bu hammaddelerin nereden alındığı belirlenebilmektedir. Paleolitik sanatta kaya yüzeyine figürlerin boyayla yapılması için ortak pigmentler olarak demir oksit, manganez veya kömür kullanıldığ1; kırmızı, turuncu ve sarı renklerin temel bileşenlerinin; demir oksit şeklinde hematit, goetit ve okr olduğu; siyah renk elde etmek için ise manganez ve karbon kullanıldığ belirtilmektedir. Ayrıca bu temel renklerle birlikte, tekrar eden biçimde, daha düşük renklendirme özelliği olan, kuvars, kalsit, alüminosilikatlar (killer) ve hatta kehribar gibi hammaddelerin de kullanıldığı belirlenmiştir. Boyalara, yoğunluk, akışkanlık ve yapışma özelliği kazandırmak için, farklı malzemelerin bilinçli olarak karıştırılarak kullanıldığı düşünülmektedir. $\mathrm{Bu}$ sonuçlar, Paleolitik resimlerde kullanılan boyalar için renk pigmenti, akışkanlık için bağlayıcı/sertleştirici ve yapıştırıcı madde olmak üzere üç temel bileşen önerilmesini sağlamıştır: Lascaux Mağarası'ndaki resimlerde siyah renk için manganez kullanılmıştır ve bu nedenle resimlerden radyokarbon tarihleme yapılamamıştır (Balbín Behrmann ve González, 2009; Chalmin ve diğerleri, 2003).

\section{Tarihöncesi Sanatta Biçim ve İçerik}

Avrupa'da tarihöncesi sanata dair ilk kalıntılar Aurignacien döneme aittir ve GÖ 35.00028.000'e tarihlenmektedir (Groenen, 2016, s. 37). Sanatla ilgili arkeolojik kalıntılar en başından itibaren, üç farklı biçimde açığa çıkmıştır. Mağara duvarlarının yüzeyindeki sanat (art pariétal), açık hava kaya sanatı (art rupestre) ve taşınabilir sanat (art mobilier). $\mathrm{Bu}$ üç farklı formda ortak olan şey hayvan betimlemelerinin yoğunluğudur. Yapım teknikleri çeşitlidir. Renk veren malzemeler boya olarak kullanılarak yapılan resimlerde, 
kırmızı (hematit, koyu sarı), siyah (mangan dioksit, kömür), sarı veya kahverengi (limonit, götit), nadiren beyaz (kaolin) kullanılmıştır. Bazıları kayaların yüzeylerine kazılarak yapılmıştır. Kazıma yöntemi, zamana, ortama ve iklime en dayanıklı grup olarak değerlendirilmektedir. Heykel tekniği ile üretilmiş eserler daha azdır. Bu durum, onları yapmanın daha zor olmasıyla açıklanmaktadır (Paillet, 2015, s. 95; Yalçınkaya, 1978, ss. 69-70). Tarihöncesi sanatın üretilme tekniklerinin, kullanılan hammaddeye, mağara veya kaya yüzeylerinin yapısına bağlı olarak değişebildiği, mağara duvarlarının veya kaya yüzeylerinin doğal biçimi ve işlenmek istenen betim arasında uyumlar yakalandığı durumlarda betim ve doğal yapının uyumlu kullanımının resme farklı bir estetik kattığına dikkat çekilmektedir (Yalçınkaya, 1978, s. 67).

\section{Taşınabilir Sanat}

Taşınabilir sanat kalıntıları heykelcikler, üzeri bezemeli aletler, kullanım işlevi belirsiz bloklar, plakalar, levhalar üzerindeki betimlerde dâhil yaklaşık 30.000'e yakın nesne ile temsil edilmektedir. Araştırmacılar, Üst Paleolitik'in birçok bağlamında, insan ve hayvan figürlerinin yanı sıra, bezenmiş ve işlenerek şekillendirilmiş kemik, boynuz, fildişinden ve taştan nesneler açığa çıkarmıştır. Temsili imgeler, soyut ve gerçekçi, boyama ve kazıma tekniğiyle üretilmektedir. Doğu Avrupa, Sibirya ve Levant gibi dünyanın diğer bölgelerinde, taşınabilir sanata dair kalıntılar bulunmaktadır. Takılar; kabuklardan, dişlerden, fildişi, devekuşu yumurtası kabuğundan imal edilmektedir. Bu takıların Üst Paleolitik'te Avrupa, Orta, Batı Asya ve Afrika'da kullanıldığı bilinmektedir. Takılar, bireylerin sosyal kimliğinin bir parçası olarak değerlendirilebilir. Az olmakla birlikte Orta Paleolitik'e tarihlenen tabakalarda da bu tür nesneler bilinmektedir. Örneğin, Güney Afrika'da Howiesons Poort'da (Barnard, 2012; Bar-Yosef, 2006, ss. 9-10).

\section{Taşınamaz Sanat}

Mağaralarda, kaya altı sığınaklarında ya da açık havada kayaların yüzeylerinde görülen betimler bu grubu oluşturmaktadır. Mağara sanatının hikâyesi 19 yy.da İspanya'da başlamaktadır. İspanya'nın kuzey kıyılarında, Cantabria Bölgesi’nde Santander şehrinin yaklaşık 30 km batısında Santillana del Mar köyündeki Altamira Mağarası ilk olarak Paleolitik sanata dair kalıntıların keşfedildiği yerdir. Mağaranın 1868'de avcı Modesto Cubillas Pérez tarafından keşfedildiği, 1875'te doğa bilimci Marcelino Sanz de Sautuola tarafından ziyaret edildiği, bazı 'grafik' olabilecek kalıntılar fark ettiği ancak bunların insan elinden çıktığına ihtimal vermediği belirtilmektedir. Marcelino Sanz de Sautuola 1878'de Paris Evrensel Fuarı'ndaki taşınabilir sanata dair kalıntıları gördükten sonra, 1879'da özel mülkünde bulunan Altamira Mağarası'nı ziyaretinde kendisine eşlik eden kızı tarafından resimlerin fark edildiği bildirilmektedir (Lewis-Williams, 2019, s. 30).

Tarihöncesi sanat kalıntıları, Sibirya'da, Avrupa'nın güney ve batı sınırlarına kadar 500'den fazla alanda açı̆̆a çıkarılmıştır. Taşınamaz sanat kalıntılarından 300'ü mağarada, 50’ye yakını kaya altı sığınağı veya mağara girişinde, bir düzine kadar açık 
hava kaya sanatı kalıntısı saptanmıştır (Paillet, 2015, ss. 95-96). Paleolitik sanata dair kalıntılar İber Yarımadası'nda İspanya ve Fransa'da ağırlıklı olarak açığa çıkarılmıştır. Bununla birlikte az olmakla birlikte İtalya, Sicilya, Yugoslavya, Romanya ve Rusya'da da kalıntılar mevcuttur. Kaya altı sığınakları ve derin mağara duvarlarına işlenmiş olarak açığa çıkarılmış kalıntıların coğrafi dağılımına baktığımızda; Fransa' da 130 alanda; İber Yarımadası'nda 108 farklı alanda kalıntılar mevcuttur. İber Yarımadası'ndaki kalıntıların 82 tanesi Kantabria-İspanya bölgesindedir. Yoğunlaşma bölgesi Franko-Kantabria olarak değerlendirilmekle birlikte dünyanın farklı bölgelerinde Paleolitik sanata dair izler mevcuttur. Bunlar: 20 arkeolojik alan İtalya ve Sicilya'da; bir alan Yugoslavya'da, bir alan Romanya'da ve bir alan ise Rusya'da saptanmıştır (Sauvet, 1994, s. 169). Birçok bölgede resim yapılabilecek kalkerden mağaralar, yeteri kadar kayalık yüzey bulunmasına karşın, Franco-Cantabria bölgesi ile aynı döneme tarihlenen yerlerde taşınamaz sanat kalıntıları açığa çıkarılmamıştır. Belki de farklı bölgelerden gelen grupların sosyal etkileşim alanı olarak Franco-Cantabrian bölgesini kullanmış olabilecekleri fikri ileri sürülmektedir (Bar-Yosef, 2006, ss. 9-10). Kaya sanat1, insanlığın günümüze kadara korunarak gelebilen sanatsal ifadelerinin en eskisidir. Bu kalıntıların bir bölümü GÖ 60.000-40.000 yıllarına kadar tarihlenebilmektedir. Kaya sanatı, iyi korunduğu bilinen derin mağaralarda, bir bölümü uçurumların eteklerinde kaya altı sığınaklarında, boşlukların girişlerinde ve özellikle açık havadaki kayaların yüzeylerinde bulunmaktadır (Clottes, 2004, s. 1). Sanatsal ürünler resim, gravür, heykel olmak üzere üç farklı teknikle üretilmektedir. Güney-Batı Fransa'da duvardaki gösterimler, ağırlıklı olarak, büyük kalker bloklar ve bu bloklardan ayrılmış parçaların üzerine derin gravür tekniğiyle işlenmektedir (Sauvet, 1994, s. 169).

\section{Kazıma Resim (Gravür)}

Tarihöncesi sanatta en çok gravür tekniğiyle üretilen eserler açığa çıkarılmıştır. Gravürlerin üretiminde, temel prensip hammaddenin (kaya, kemik vb.) yüzeyinden çizgisel parça çıkararak resim yapılmasıdır. Farklı tekniklerle kazıma resim yapılmaktadır. Yaygın olan küçük darbelerle parça çıkarma tekniğidir. Bu yöntemde çay taşı gibi sert bir taş kullanılarak, kayanın yüzeyine kontrollü küçük darbeler uygulanarak yüzeyden parçacıklar çıkarılmaktadır. Kayaların yüzeyleri, özellikle kurak bölgelerde, zamanla yıpranmakta, elementlerin etkisi ile fiziksel ve kimyasal olarak değişerek, dış yüzeyinde paslanma veya patinalaşma ${ }^{12}$ sonucunda iç ve dış rengi arasında farklılaşma oluşmaktadır. Kayanın yüzeyine uygulanan küçük darbeler, yüzeysel mikro tabakanın kalkmasına ve içerdeki daha farklı, kimi zaman daha açık renkli kaya yüzeyinin ortaya çıkmasını sağlamaktadır. Yan yana ve üst üste uygulanan darbeler/etkilerle oluşturulan çizgiler ve parça kaldırılan/oyulan kısım ve kaya yüzeyinin korunduğu arka plan arasında

${ }^{12}$ Patina: Aşınım yüzeyi olarak da adlandırılmaktadır. Kayaç yüzeyinin geçirdiği süre içerisinde dış etkenler nedeniyle değişime uğramasına verilen isimdir. Kaya yüzeyinin geçirdiği süre ve ortamdan etkilenme derecesine bağlı olarak yüzeyden başlayan bozulma içeriye doğru bir tür pas olarak devam etmektedir (Özdoğan, 2019, s. 70). 
oluşan renk kontrastları yardımıyla da kaya yüzeylerinde resimler daha belirgin hale gelmektedir. Bu teknik bütün dönemlerde ve dünyanın tüm kıtalarında resim yapmak için kullanılmaktadır. Bir diğeri kesme ve kazıma yöntemidir. Kesme yönteminde keskin kenarlı olasılıkla bir yontma taş aletle kaya yüzeyinden keserek parça çıkarılmaktadır. Kazıma da kaya yüzeyi belirli bir derinlikte kazılarak çizgisel hatlar açılması yoluyla betimlemeler oluşturulmasıdır. Bu tekniklerde de renk kontrastları ve çizgilerin ortak kullanımı söz konusudur. İnce çizgilerle oluşturulan gravürler, parça çıkarmanın etkisiyle kayanın üzerinde daha açık renkte alanlar oluşturduğu için, açıkça göze çarpmaktadır. Bununla birlikte, aradan geçen uzun zamanlardan sonra, ince çizgilerin içinde doğal etkilerle patinalaşma oluşabilmekte ve kayanın diğer yüzeyleriyle aynı rengi alabilmektedir. Bu tür ince gravürlerin ayırt edilmesinde, farklı açılardan verilen yapay 1şıklar veya açık hava kaya sanatında günün farklı saatlerinde 1şığın farklı açılarından yararlanılmaktadır. Afrika'da bazı örneklerde, olukların düzenli hale getirmek için derin gravürler cilalandığı bildirilmektedir (Brot, 2012; Clottes, 2004).

\section{Boyalı Resim}

Tarihöncesi sanatta, mağara duvarlarına ve açık havadaki kayalık yüzeylerde boyama tekniğiyle yapılan resimler açığa çıkarılmıştır. İki farklı ortamdaki bu resimlerdeki renkler, mağaraların içinde oldukça iyi korunmakta, Paleolitik Dönem açık hava kaya resimlerinde ise boyalar yoğun tahribata maruz kalmakta, bu nedenle de özel koruma gerektirmektedir. Bu teknik renk bırakan bir "şey" ile mağara duvarlarına veya açık havadaki kayaların yüzeylerine çizim yapılmasını temel almaktadır. Boyama, el parmağıyla, bir çubukla, bir sopayı kalem gibi kullanılarak yapılabilmektedir. Örneğin bir ahşap parçasının ucu yakılarak (karbon kullanılarak) siyah renk elde edilerek, bununla kaya yüzeylerine çizim yapılabilmektedir. Chauvet Mağarası'nın tüm siyah figürleri karbon kullanılarak yapılmıştır (Balbín Behrmann ve González, 2009, s. 559; Clottes, 2004; Théry-Parisot ve ark., 2019). 


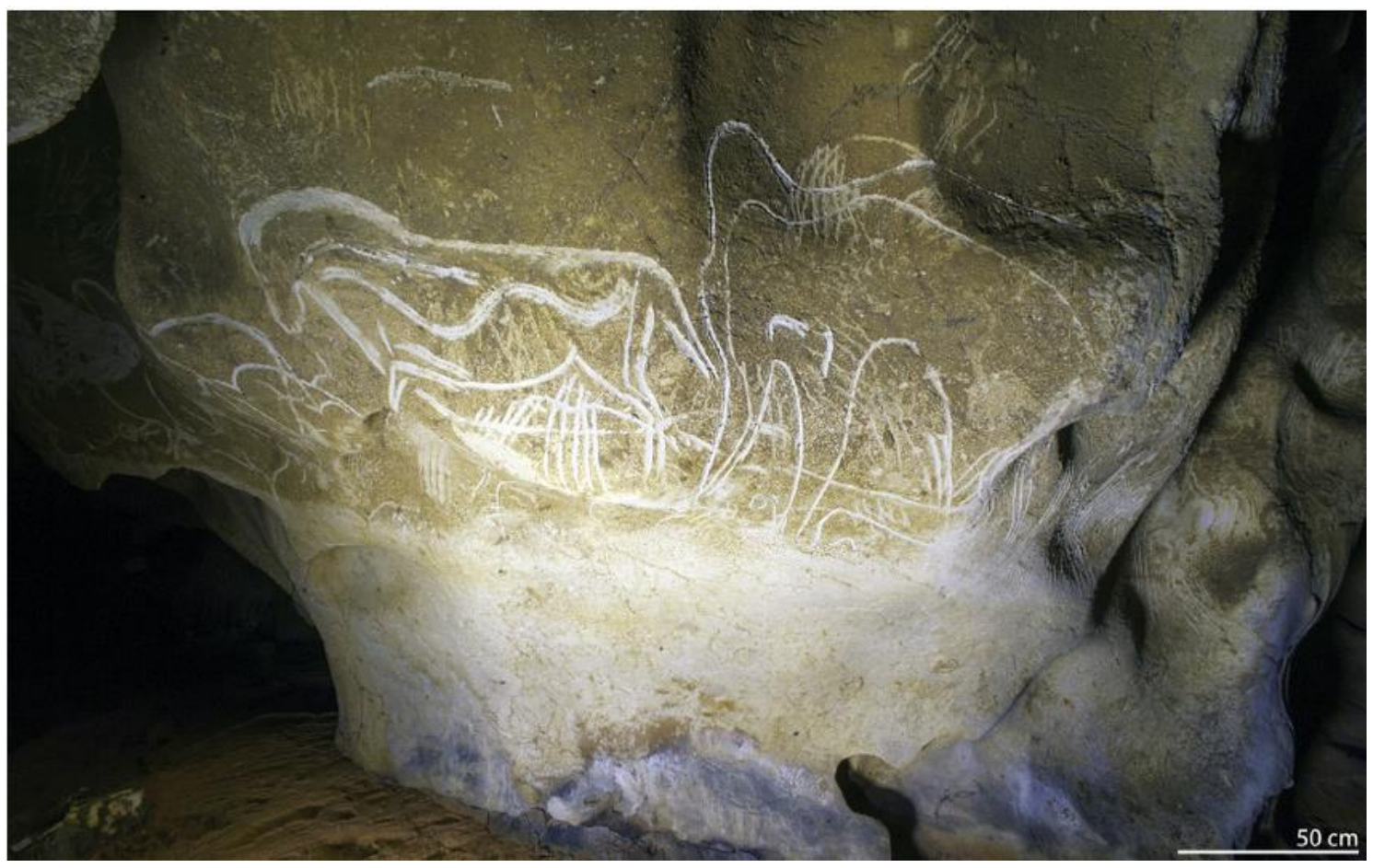

Figür 5. Chauvet Mağarası Hillaire Salonu, gravür Atlar Paneli (Fritz ve Tosello, 2015, Figür 6).

Resim yapmak için kullanılan sıvı boyaların kaya yüzeylerine uygulanmasında kullanılan teknikler de çeşitlidir. Uygulamada en yalın ve dolaysız yöntem, kişinin boyaya parmağını batırıp, parmağını bir kalem gibi kullanarak boyayı kaya yüzeyine sürmesidir. Hayvan kıllarından yapılan firçalar ve hayvan derisinin de resim yapmak için kullanılabileceği, ayrıca şablon tekniğinin de icat edilmiş olduğuna dikkat çekilmektedir. Şablon tekniğinde çizilmek istenen desenin kaya yüzeyine sabitlendiği, resim yapmak için kullanılacak sıvı malzemenin ağza alınarak yüzeye sabitlenen nesnenin üzerine üflenerek yayıldığı, devamında seyyar olarak yüzeye sabitlenen "kalıp" çıkarılarak, negatif izlerin çevresindeki konturların resmi oluşturduğu belirtilmektedir. Bu yöntemle özellikle el resimlerinin yapıldığı belirtilmektedir. Bir diğer yöntem, delikli resim kalıbı tekniğidir. Bu teknikle, lekeler yardımıyla ilginç kabartılar oluşturularak resim elde edilmektedir. Marsilya yakınlarındaki Cosquer Mağarası'nda GÖ 27.000 ila 28.000 yıla tarihlenen negatif el izleri mevcuttur (Clottes, 2004; Langaney ve ark., 2000, ss. 62-63). 


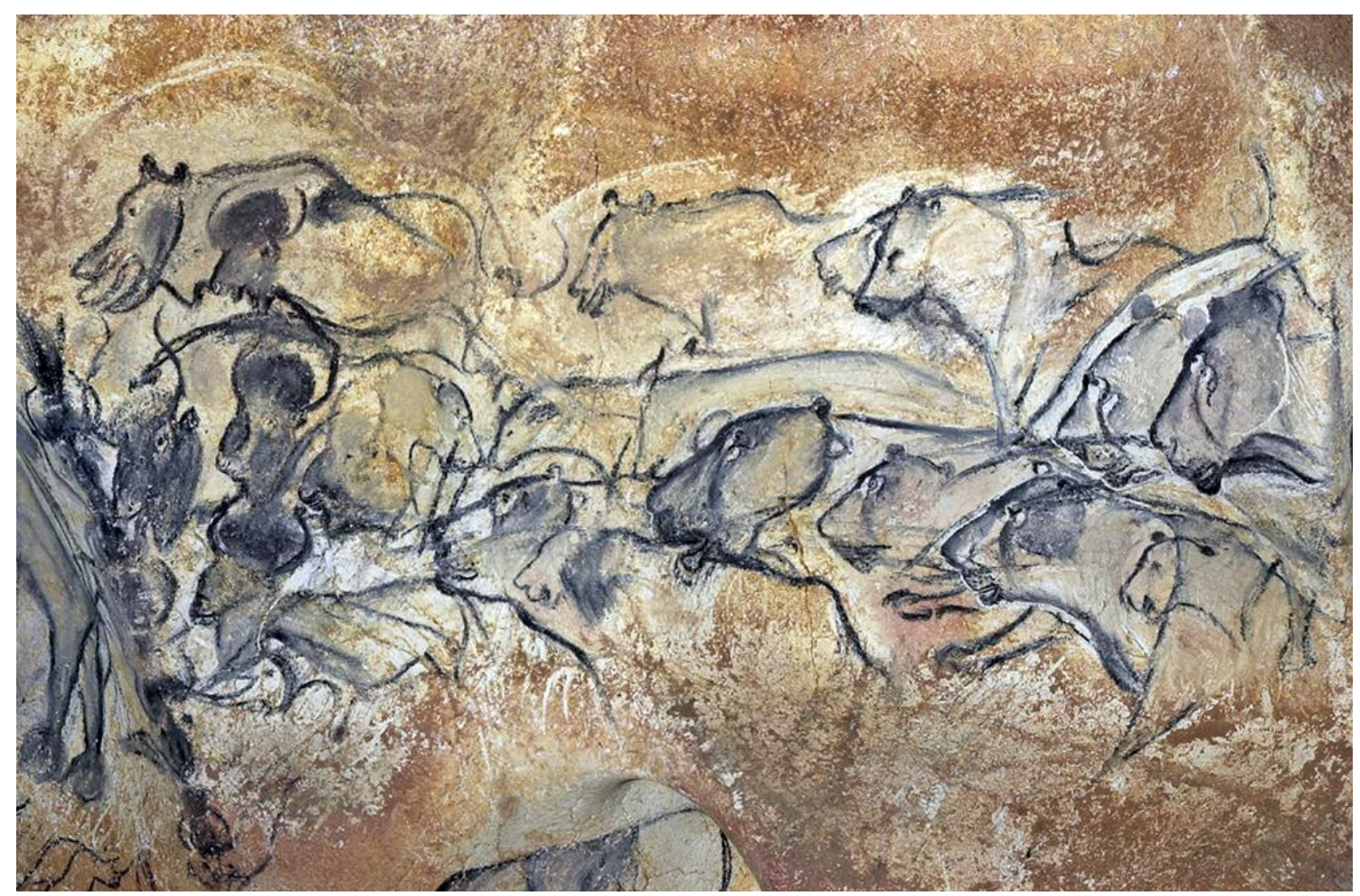

Figür 6. Chauvet Mağarası, karbonla yapılmış resimlerden örnek (Azame, 2015, figür 10).

\section{Tarihöncesi Sanatta İşlenen Konular}

Mağara sanatının ayırt edici özelliklerinden biri, figüratif (mecazi) ve figüratif olmayan öğeleri içermesidir. Figüratif desenler -tanınması zor hayvanlar- neredeyse her zaman bunlara geometrik motifler eşlik etmektedir. Çubuk biçiminde motifler, taşınabilir sanatta kemik nesneler üzerinde aynı biçimde ritmik halde geometrik biçimler görülür. Figüratif motifler yalnızca canlı varlıklar; insanlar ve hayvanlardır, bitki ya da peyzaj betimlemeleri bulunmamaktadır (Sauvet, 1994; Vialou, 2009, s. 471).

\section{Insan Betimleri}

Tarihöncesi mağara sanatında insan tasvirleri, hayvan tasvirlerinin büyük bir bölümünün tersine, natüralist olmadığı, kişinin görünüşüne veya tamamen insan anatomisini yansıtan portre veya siluet görmenin istisnai bir durum olduğu, insanın bir şekil bozumuna uğratılarak, şematik resmedildiğine dikkat çekilmektedir (Vialou, 2009, s. 473). Tarihöncesi sanatta insan betimleri yaygın değildir. Betimlerin yaklaşık \%4'lük oranına denk geldiği belirtilmektedir. Gravettien dönemden başlayarak Üst Paleolitik boyunca insan betimleri tarihöncesi sanatta resmedilmektedir. Yaklaşık olarak GÖ 18.00011.000'lere tarihlenen Magdalenien dönemde bu grupta bir artış (yaklaş1k 413 figür) ve ifade biçimlerinde bir farklılaşma ortaya çıktığı, önceki dönemlerden farklı olarak, sanat kalıntılarında, deforme edilmiş insan betimlerinde bir biçim çeşitlenmesinin ortaya çıktığı ileri sürülmektedir. Vücudun geri kalanından izole edilmiş yüzün temsili ile yeni 
temaların ortaya çıkması, kişinin kendi imajıyla yüzleşme arzusu olarak yorumlanmaktadır (Groenen, 2000, s. 7; Fuentes, 2015, s. 172). Fuentes (2015, s. 173, Tablo 1) insan figürlerini A. Leroi Gourhan'ın (1992, ss, 295-305) ayrımlarını temel alarak, gerçekçi figürler, gerçekçi olmayan figürler ve stilize edilmiş figürler olmak üzere üç grupta sınıflamaktadır. Bir görüntünün insan vücudunu temsil ettiğinin ayırt edilebilmesi için, görüntünün, en az insan karakterize eden tipik bir uzuv, bir davranış biçimi, insanı çağrıştıracak temel özellik içermesi gerektiğine dikkat çekmektedir. İnsan gövdesini çağrıştıran kalça, gögüs, omuz, göbek, cinsel organlar vb. üst uzuvları temsilen eller, kollar, parmaklar; alt uzuvlar için bacak, diz, ayak, ayak parmakları; kafa bölgesi için boyun, ense, saç, alın, burun; yüz için ağız, bıyık, çene, sakal; göz için kaş, kirpikler gibi detaylarla temsil edilmektedir. Betimler, sadece kafa, kafa ve gövde, sadece gövde, genellikle antropomorfik olarak adlandırılabilecek nitelikte ve insan elinin ve cinsiyetlerin izole gösterimleri, şemalar ve birleşik karakterler olarak birkaç kategoride sınıflanmaktadır. Kompozit figürler, özellikle hayvan nitelikleri olan insanlar, hayali bileşenlerin varlığının göstergesi olarak değerlendirilmektedir (Groenen, 2016, s. 37; Fuentes, 2015). Üst Paleolitik Dönem kadın temsillerinde betim çeşitliliği söz konusudur. Kadın figürlerinde ergenlik öncesinden menopoz sonrasına farklı yaş kategorilerinde kadınların betimlendiği belirtilmektedir. Kadın bedenleri farklı kilolarda, ince yetişkin kadınlar, hamile kadın, doğum anı veya öncesinde gösterilmektedir. Kadınların giysileriyle özenle süslenmiş detaylarla resmedildikleri, bir kadının kolunda bilezik, bir diğerinde kemer, kolye vb. takılara da yer verildiği belirtilmektedir. Elinde bir boynuz ve saçların işlenişindeki özenle betimlenen kadın dikkat çekici olarak yorumlanmaktadır. Magdalenien Dönem'e tarihlenen La Marche'deki sanata dair kalıntılarda çocuk hatta yeni doğmuş bebek betimlerinin de bulunduğu belirtilmektedir. Erkek betimlerinde ereksiyon halindeki penisin ya da penis kılıfının erkeksi karakteri vurguladığ düşünülmektedir. Bunların cinselliği çağrıştıran bağlamlarda olmadığı, tek başına veya bir hayvanla mücadele içerisinde betimlendiği, bazı figürlerdeki erkeksi karakterin sakal veya bıyıkla da vurgulandığına dikkat çekilmektedir. Resimlerdeki detaylardan erkeklerin yaşının çok ayırt edilemediği, bununla birlikte genç ve yaşlılara ait betimler olduğu düşünülmektedir (Groenen, 2000). En sıra dışı figürler, théranthropes, kompozit yaratıklar insan ve hayvan özellikleri barındırırlar. Bu tip de farklı varyasyonlarla belirlenmiştir. $\mathrm{Bu}$ betimlerin çok eski evrensel inançlarla ilişkili olabileceği ileri sürülmektedir. İnsanlar ve hayvanlar arasındaki sınırların geçirgenliği, hayvan türlerine ait nitelikleri insanlara atfetme durumu olarak yorumlanmaktadır (Clottes, 2004). 

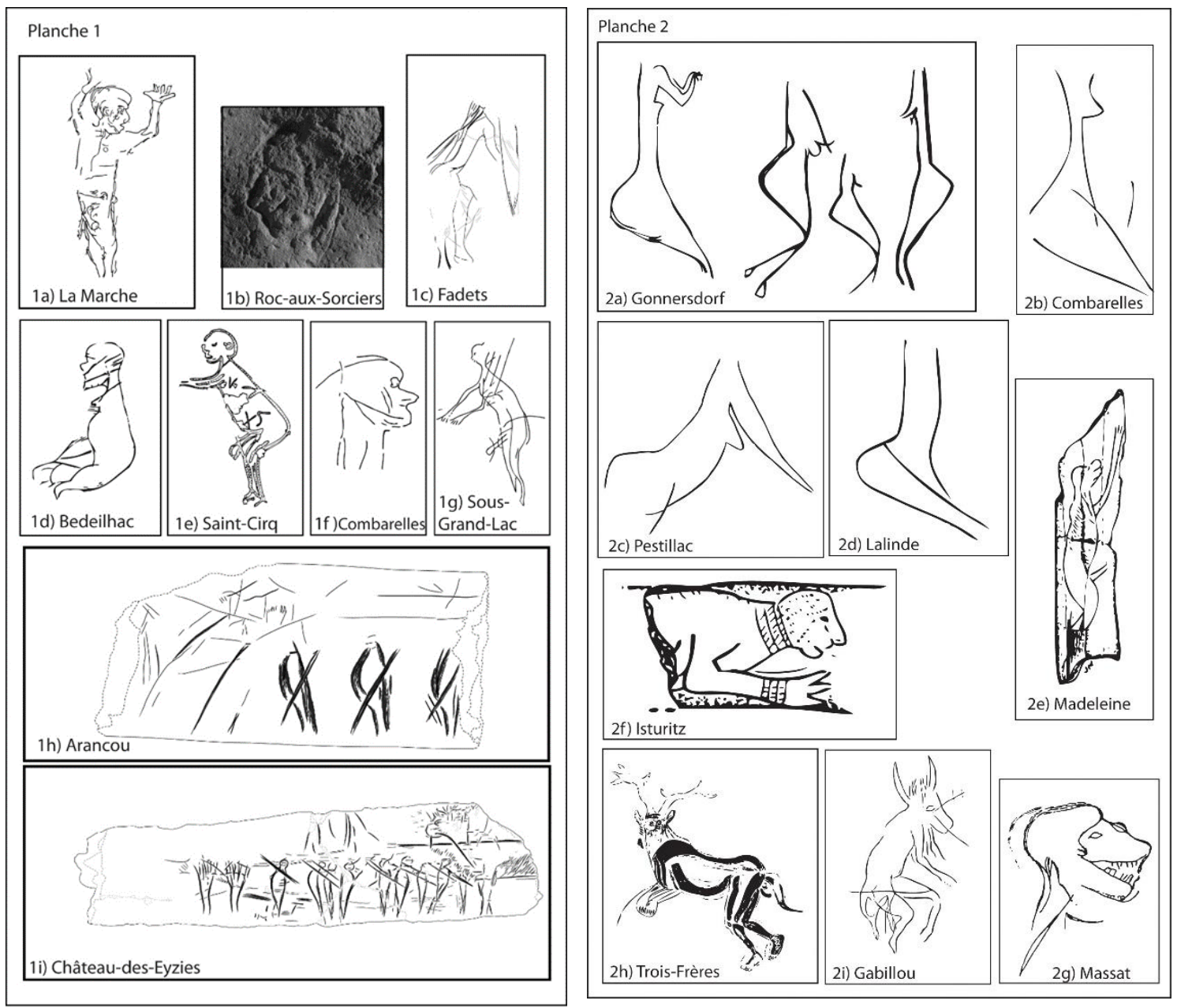

Figür 7. Tarihöncesi sanatta insanların betimlenme biçimleri (Fuentes, 2015, Planche 1 ve 2).

\section{Hayvan Betimleri}

Tarihöncesi sanat kalıntılarında yoğun olarak hayvanların betimlenmiş olması, tarihöncesi insanlarının sembolik evreninin merkezinde hayvanların yer aldığına dair önemli bir gösterge olarak değerlendirilmektedir. Hayvanları avlayan ve gözlemleyen avcıların sanatı olarak natüralisttir. Estetik ve üslup açısından değerlendirildiğinde kültüre has özellikleri yansıtan "sanatçıların” eseri olduğu düşünülmektedir. Betimlerde bazen kafalar küçük, uzuvlar inceltilmiş, boynuzlarda orantısızlıklar gibi, doğal betimlerin yanı sıra "deformasyonlarla" sanatçılar etraflarındaki görüntünün taklidini değil, "kendine” görüneni resmetmeye odaklandığı yorumu yapılmaktadır. Üst Paleolitik sanatın "özneleri” ağırlıklı olarak otobur olan büyük memelilerdir. Bunlar yaklaşık 20 tema çerçevesinde işlenmekte ve bunlara "işaret-motif”" olarak adlandırılan soyut çizimler eşlik etmektedir (Azame, 2006, s. 479; Paillet, 2015, s. 96). 
Azame (2006), Üst Paleolitik sanatı icra edenlerin öncelikle avc1-toplayıc1 gruplardan insanlar olduğuna, bu anlamıyla avladıkları ya da karşılaştıkları hayvanları davranış, biçim, hareket ve tarz açısından iyi tanıdıklarına dikkat çekmektedir. Hareketi resmi yapan için olasılıkla hayvanı tanıma ve dolayısıyla temsil etme sürecinin ayrılmaz bir parçası olarak yorumlamaktadır. Bu duruma Lascaux'daki Boğalar Salonu veya Fond de Chauvet Salonu'ndaki büyük paneli örnek göstermektedir. Kompozisyonlardan hareketle, animasyonu mağara sanatının temel dinamiği olarak değerlendirmekte, "Animasyon = hareket temsili" olarak ifade etmektedir. Mağara duvarına çizilen bir hayvanın, onun davranışsal durumunu ortaya koyduğunu varsaymaktadır. Betimlerde hareketliliği göstermek için zaman içinde değişen hareketi grafiksel olarak bir biçime dökmek için iki yöntem kullanmışlardır: İki hareketi ayrıştırmak için ardışık görüntülerin üst üste bindirilerek işlenmesi ve ardışık görüntülerin yan yana getirilmesi (Azame, 2006, s. 479,490$)$.

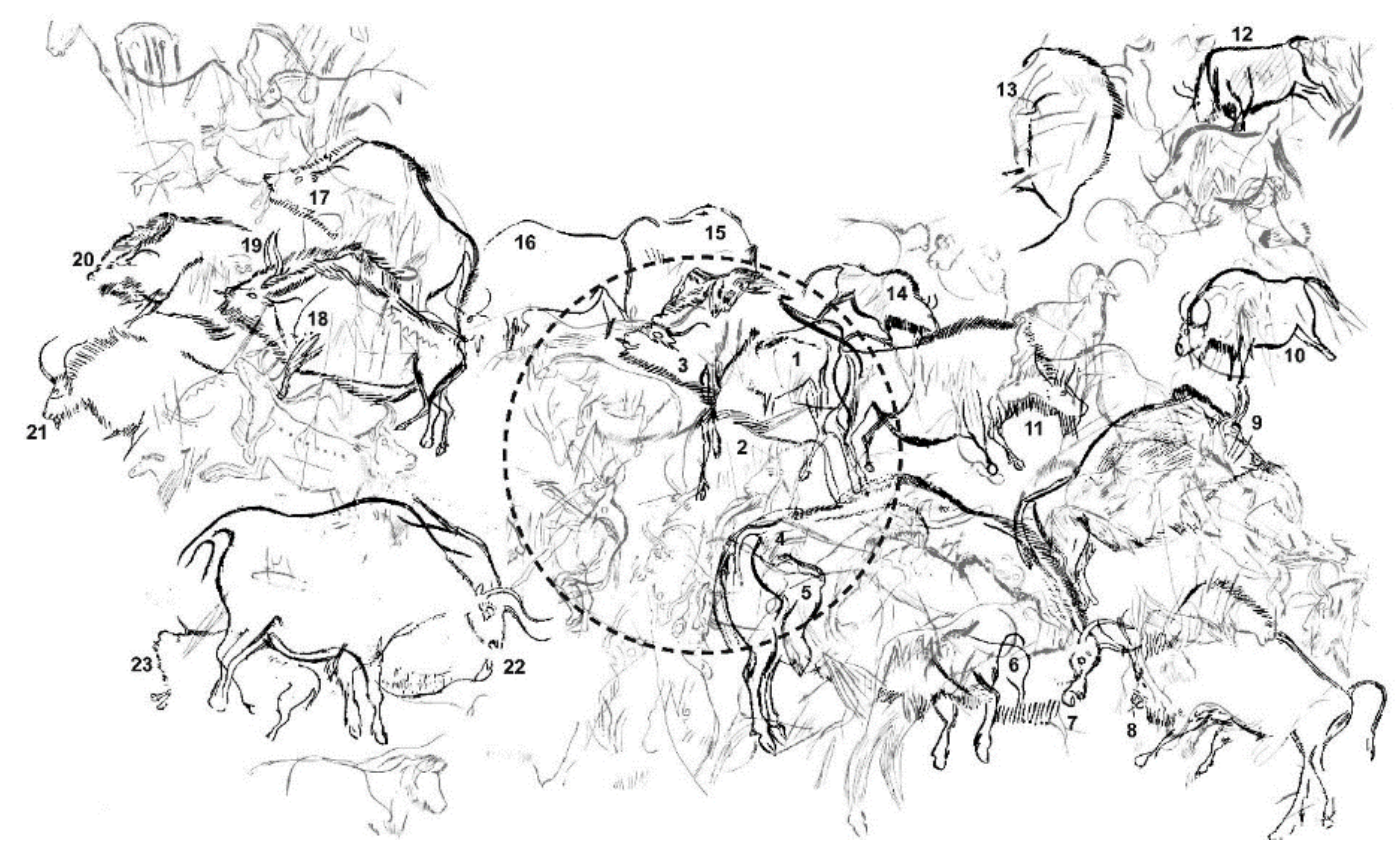

Figür 8. Les Trois-Frères Mağarası'nda hareket halindeki bizonlar (Azame, 2006, Figür 9).

Fransa'da 86, İspanya'da ise 68 alandan 3981 figürün analiz sonuçları, Üst Paleolitik sanatta tasvir edilen hayvan betimlerinin sayısal dağılımı için bir fikir oluşturmaktadır. 


\begin{tabular}{|l|l|l|}
\hline Resmedilen hayvan & Sayısı & Yüzdesi \\
\hline At & 1099 & 27,6 \\
\hline Bizon & 820 & 20,6 \\
\hline Dağkeçisi & 396 & 9,9 \\
\hline Mamut & 341 & 8,6 \\
\hline Geyikgiller & 265 & 6,7 \\
\hline Yaban Öküzü & 228 & 5,7 \\
\hline Geyik & 203 & 5,1 \\
\hline Ren Geyiği & 138 & 3,5 \\
\hline Antropomorf figürler & 134 & 3,4 \\
\hline Aslan & 90 & 2,3 \\
\hline Gergedan & 75 & 1,9 \\
\hline Ayı & 67 & 1,7 \\
\hline Balık & 39 & 1 \\
\hline
\end{tabular}

Tablo 1. Üst Paleolitik sanatta tasvir edilen hayvan betimlerinin sayısal dağılımı (Sauvet ve Wlodarczyk, 2001, s. 221, Tablo 1).

Mağara duvar sanatının \%90'ından fazlasını tanımlamak için sekiz hayvan türü yeterlidir (Sauvet, 1994; Groenen, 2016). Chauvet Mağarası'nda, kedigillerin bıyıklarından ayının yuvarlak kulaklarına ve geyiklerin göz pınarlarına kadar ince anatomik detaylar işlenmiştir. Buna ek olarak, hayvanlar o denli “gerçekçi”” betimlenmektedir ki, çoğunlukla hayvanın cinsi veya türü, ama aynı zamanda davranış veya mevsimselliği hakkında bilgi sunmaktadır. Dişi geyik, mamut, Ren geyiği gibi bazı hayvan motiflerinin sayısal dağılımı, yerel ve kronolojik olarak hassas bir çeşitliliğin varlığına işaret etmekte, buna karşın at, dağkeçisi ise istikrarlı bir ortak fonun varlığını akla getirmektedir. Betimlenen hayvanlar genellikle, resimlerin bulunduğu bölgede olan hayvanların yoğunluklarıyla paralellik göstermez. Resmediliş gerçekçi olmakla birlikte, çizilenler hayvan doğasının bire bir taklidi değildir. Betimleyicilerin olasılıkla çevrelerindeki hayvan dünyasının görüntüsünü veya avladıkları, tükettikleri hayvanları yansıtmayı da hedeflemedikleri ileri sürülmektedir. Hayvan seçiminde, resmedilecek hayvana yüklenen simgesel anlamın belirleyici olduğu varsayımı ağırlık kazanmaktadır (Clottes, 2004; Paillet, 2015, s. 96). Özellikle Fransa'daki mağaralarda betimlenen hayvanlar üzerine yapılan çalışmalarda, eril ve erişkin hayvanın hareket halinde betimlenmesinin daha yaygın olduğuna, örneğin bizonların \%67'sinin eril olduğuna dikkat çekilmektedir (Azame, 2006, s. 480). 


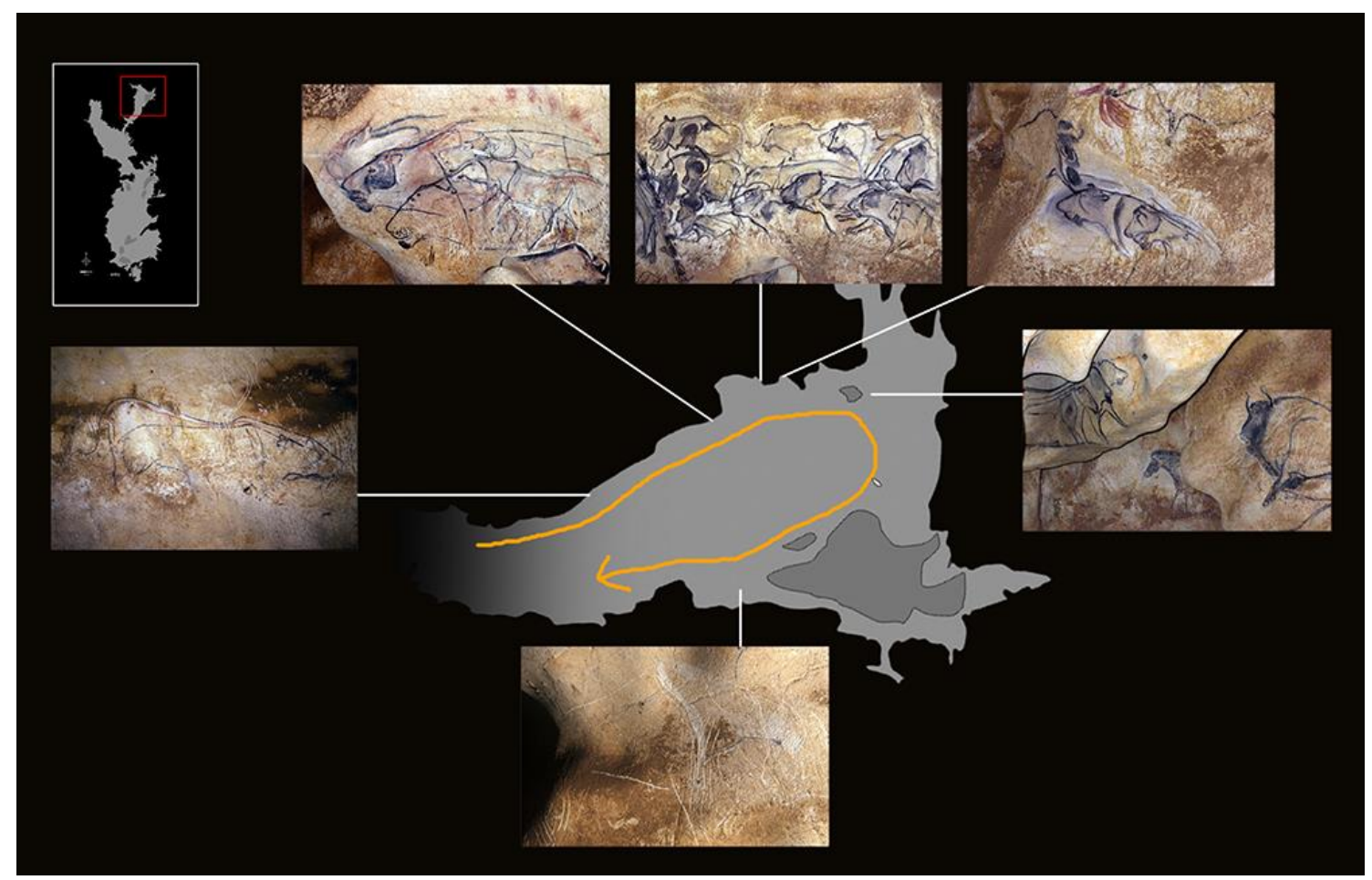

Figür 9. Chauvet Mağarası Salle du Fond'da mağaranın ana temalarından biri olan mağara aslanının, yaşam döngüsünün farklı aşamalarında (üreme, yiyecek) tasvir edildiği belirtilmektedir (Azame, 2015, Figür 15).
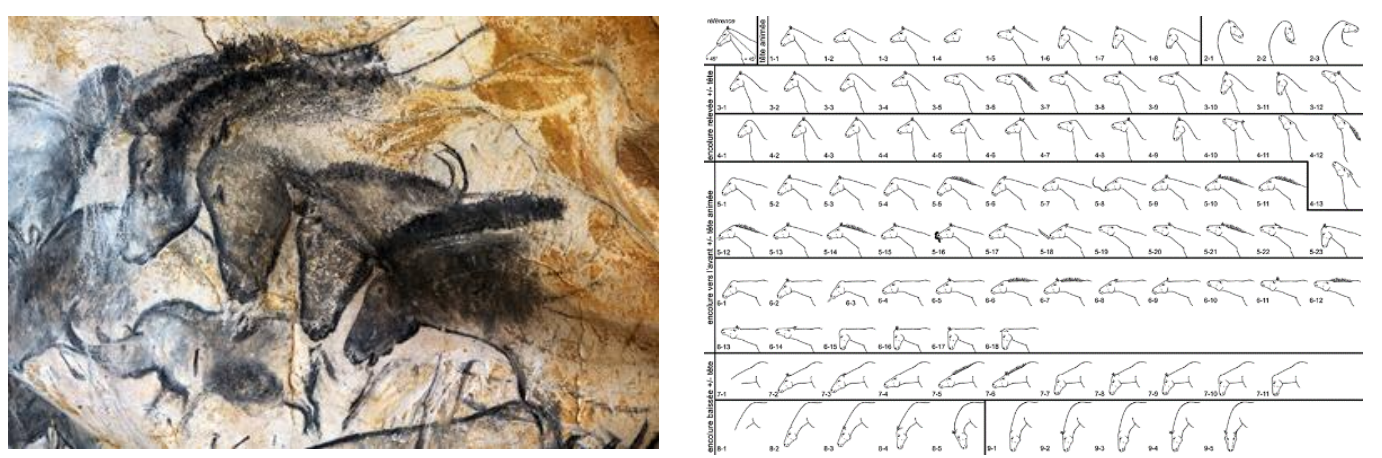

Figür 10. Chauvet-Pont d'Arc Mağarası'ndan At Paneli (Azame, 2015, Figür 17) ve Fransa'daki mağaralarda betimlenen atların baş ve boyun hareketlerinin sınıflandırılması (Azame 2006: Tablo 2).

\section{Motifler}

Figüratif olmayan temsiller kategorisi, işaretleri, genellikle bol ve tekrarlayan bu basit veya karmaşık geometrik şekilleri, desenleri, tanımlanamayan ve yalnızca bir veya çok az kopya halinde var olan bu geometrik tasarımları bir "ikonografik set" içinde bir araya getirir. Bu çizgiler, sadece onları orada bırakmak veya onlara dokunmak edimiyle duvarlarda birakılan izler olarak da yorumlanabilmektedir (Vialou, 2009, s. 471). Piktogramlar, ideogramlar ve/veya mitogramlar ya da tümüne birden işaretler/motifler 
denirse, bunların tüm Paleolitik ikonografide, figüratif resimlerden daha fazla oldukları belirtilmektedir. Motiflerin/İşaretlerin geometrik ve sembolik olarak Paleolitik'ten başlayarak, insanlar tarafından geliştirilen kavramsal ve sosyal kapasiteleri ifade etme ve iletişim için kullanıldığg, gösteren ve gösterileni ilişkilendirdiği iddia edilmektedir. Çubuklar, kısa çizgiler, oval veya daire, noktalamalı işaretlerinin basit temel yapı işaretleri olduğu, parantezler veya aviform, köşeli, klaviform, dikenli, bölmeli dörtgen, merdiven şeklinde, çatı şeklinde olanların ise daha ayrıntılı yapıları simgeledikleri düşünülmektedir. Temel işaretlerin kültürlerarası olabileceği, daha yapılandırılmış ikinci grup işaretlerin ise bölgesel özellikleri simgelediği ileri sürülmektedir (Paillet, 2015, s. 98). Belirgin bazı desenler, her zaman her yerde görülmektedir. Örneğin minyatür kadeh formu genelde, kadınsı kabul edilmekte ve doğurganlık düşüncesiyle ilişkilendirilmektedir. Tüm kaya sanat1, herhangi bir gerçekliğe karşılık gelmeyen ve kültür dışındaki biri tarafından da tanınabilecek çizgisel betimler içermektedir. Bunlar zikzaklar, dalgalı bantlar, çizgiler, katmanlar, daireler ve dikdörtgenler halinde noktalama serileri, düz çizgiler, yalıtılmış veya gruplar halinde dikey, eğik veya yatay çizgilerdir (Clottes, 2004; Robert, 2012; Sauvet 1994). Bazen hayvanlarla ilişkili, bazen de gruplandırılmış işaretler vardır. Bir tipoloji oluşturmak çok zor olsa da formların çeşitliliği bir ila iki düzineyi geçmez. Çubuklar ve noktalar hem en soyut hem de en sık kullanılan kalıplardır. Üçgenler ve ovaller, kadın cinsiyetinin muhtemel sembolik soyutlamalarıdır. Ok veya şevron işaretleri, çoğunlukla hayvanlarla yakın ilişki içinde, muhtemelen silah ve yaralanma atma temsili olarak değerlendirilir (Sauvet, 1994).

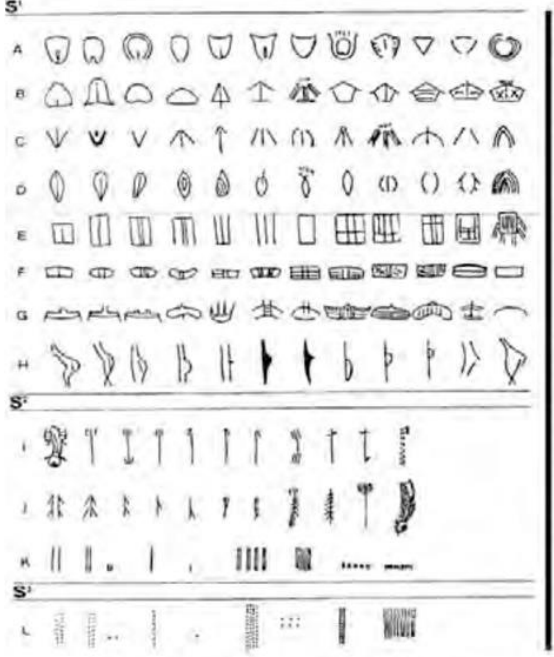

Typologie des signes Leroi-Gourhan

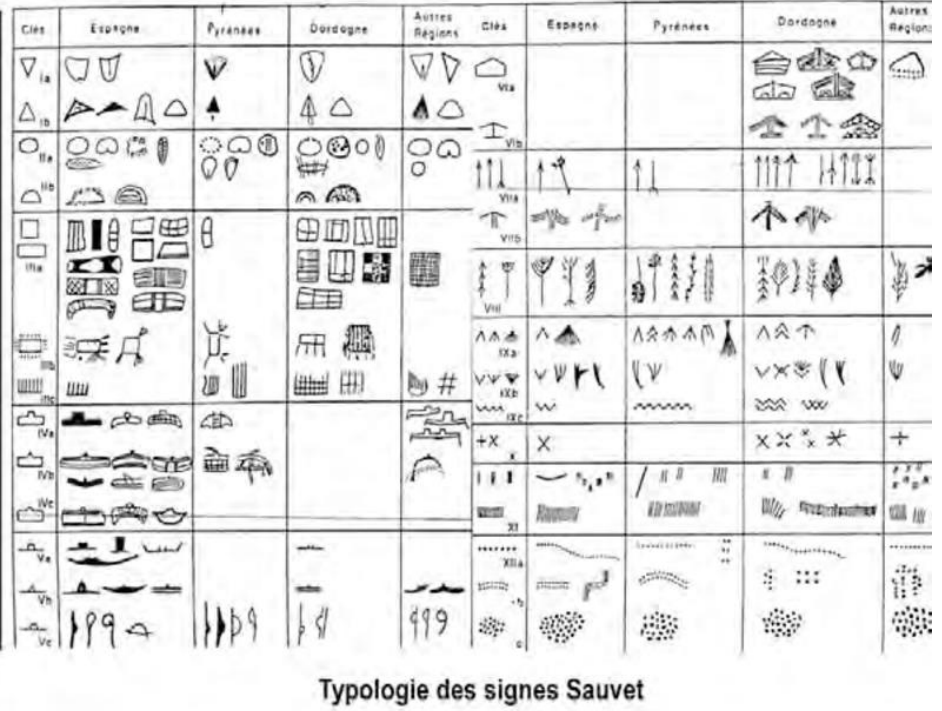

Typologie des signes Sauvet

Figür 11. Tarihöncesi sanatta motiflerin/işaretlerin sınıflanması (Robert, 2012, Figür 1). 


\section{Tarihöncesi Sanatın Yorumlanması}

Kaya yüzeyinde görüntüler oluşturmak genellikle dünyayı etkilemenin/dünya üzerinde var olmanın bir aracı olarak değerlendirilmektedir. Görüntü, temsil edilen konunun yayılması olarak algılanır, onunla yakınlık kurulmasına ve ona ulaşmasına izin verir, tehlikeleri önler ve doğanın dengesine katılır. Tarihöncesine ait ilk sanatsal kalıntılar açığa çıktığı zamandan bugüne, kalıntıların analizi, tarihlenmesi gibi çalışmaların yanı sıra, resimlerin neden yapıldığı, anlamı, nasıl bir işlevi yerine getirdiğine dair hipotezler üretilmiştir. Sanat için sanat yaklaşımı, totemizm ve av büyüsü hipotezi, Marksist bakış açısıyla resimlerin yorumlanması, Laming-Emperaire ve A. Leroi-Gourhan'ın yapısalcılık bakış açısı. D. Lewis-Williams ve J. Clottes (1996) tarafından savunulan Şamanizm yaklaşımı ve buna yönelik eleştiriler gibi birçok farklı hipotezi içermektedir (Clottes, 2003; Djindjian, 2009).

19. yy.da tarihöncesine yönelik çalışmalarda toplumların yalın ve çizgisel bir evrim süreci takip ederek belirli bir ritim içerisinde var oldukları veya değişime uğradıkları yaklaşımı hâkimdi. Tarihöncesi sanatına ait ilk kalıntıların yorumlanmaya başladığı ilk dönemlerde, açığa çıkarılan taşınabilir ve taşınamaz sanat ürünleri, sanat için sanat, eğlence için sanat, naif sanat, boş zaman geçirirken yapılan şeyler olarak değerlendirilmiş, sembolik anlamlar yüklenmemiştir. Özellikle sanat için sanat görüşünü Edouard Piette savunmuştur (Richard, 1993, ss. 60-62). Salomon Reinach, döneminin antropoloji ve sosyoloji yaklaşımlarından da etkilenerek, tarihöncesi sanatı totemizm yaklaşımıyla yorumlayan araştırmacılardandır. Totemizm en yalın halde, bir insan grubu ile bir hayvan veya bitki arasında ayrıcalıklı bir ilişkinin varlığını ifade eder. Belirli bir grup, totemi kabul ettiği hayvan veya bitki ile özdeşlik kurar ve onu kutsal kabul edebilir. Mağaralardaki hayvan betimlerinin orada yaşamış insanlar için totemsel anlamı olduğu ileri sürülmüş ancak uzun süre geçerliliğini koruyamamıştır. Özellikle resmedilen bazı hayvanların insanlar tarafından öldürülmüş biçimde betimlenmesi grup için önemli veya kutsal olma halini tartışmalı hale getirmiştir (Clottes, 2003, s. 6; Lewis-Williams, 2019, s. 45). Tarihöncesi sanatta hayvanları avlamada başarı sağlamak için yapılan "av büyüsü" çerçevesinde resmedildikleri fikri, totemizm yaklaşımı gibi etnoarkeolojik bakış açısıyla oluşturulmuş yorumlardandır. Bu yorumu ileri süren araştırmacılardan Henry Breuil'in araştırma yürüttüğü Niaux Mağarası'nda hayvanlar üzerinde ok saplanmış, yaralanmış gibi görüntülerin olması bu bakış açısını desteklemiş olmalıdır. Diğer figürlerden bağımsız durduğu izlenimi oluşturan, bazı hayvan postu giymiş gibi resmedilen antropozoomorfik görüntüdeki betimlerin varlığı da av büyüsü yorumlarını destekleyen öğeler olarak yorumlanmaktadır (Djindjian, 2009, s. 5; Lewin, 1998, s. 185).

Max Raphael, tarihöncesi sanatı Marksist bakış açısıyla yorumlayan araştırmacılardandır. Breuil çok sayıda mağarayı ziyaret etmiş ve rölövelerini çıkarmış olmasına karşın figürleri tekil öğeler olarak ele almıştır. Max Raphael, betimlerin bağlamlarıyla ve birbirleriyle ilişkisel olarak değerlendirilmesi gerektiğini ileri sürerek yeni bir bakış açısı 
geliştirmiştir. Resimlerin belirli kompozisyonlar biçiminde betimlendiğini, aynı konunun aynı mağarada farklı zamanlarda işlendiğini ve bu kompozisyonların da belirli anlamlara gönderme yaptığını ileri sürmüştür. Ayrıca mağaralardaki figürlerin ikilikleri kimi zaman da karşıtlıkları içerdiğine dikkat çekmiştir (Raphaël ve Schaefer, 1974; Lewis-Williams, 2019, ss. 51-54). Annette Laming-Emperaire ve Andre Leroi Gourhan ${ }^{13}$ mağara sanatını yapısalcılık çerçevesinde ele alan, hayvanları birbirleriyle ve mağaradaki konumlarıyla ilişkilendirerek, mağaraların mekânsal analizini yapan bilim insanlarıdır. A. LeroiGourhan, yaptığı çalışmalarda betimlerin nicel verilerini titizlikle toplayıp, istatiksel analizlere tabi tutarak hipotezlerini arkeolojik kalıntıyla doğrudan ilişkilendirmekte ve sezgisel yorumlarla tarihöncesi sanatın anlamını yeniden kurgulamaya özen göstermektedir. İki büyük otobur, at ve bizonun, genellikle her bir mağaranın ana bileşimlerinin merkezi çekirdeğini oluşturduğuna dikkat çekmektedir. Erkek ve dişi değerlere atfettiği iki karşıt ilkeye dayanan ikili bir teorik model önermektedir. Büyük dinlerin böyle bir ikilik (yin ve yang vb.) üzerine kurulduğunu ileri sürmektedir. Sembolleri sınıflandırmasında ise, ince işaretler olarak adlandırdığı çubuklar, oklar, dallı işaretlerin fallusu ve katı işaretler olarak adlandırdığı üçgenler, dörtgenler, ovallerin ve profilden betimlenen kadın bedeninin kadını simgelediğini belirtmektedir. Figürlerde ise at erkekliği, bizon ve yaban öküzü dişiliği simgelemektedir. Laming-Emperaire ise bu konuda farklı düşünmektedir. Bizonun erkekliği, atın ise kadınlığı simgelediğini ileri sürmektedir. Leroi-Gourhan mağara sanatının belirli bir gelişim çizgisi içerdiğini düşünmekte ve bunları dönemlere göre stillere ayırarak bir standartlaşma ile açıklamaktadır. Leroi-Gourhan'ın hipotezleri kurduğu sistematik yoğun eleştirilere maruz kalmakla birlikte, onun en büyük katkılarından biri, önemli buluntu topluluklarının detaylı olarak tanınmasını, bütün mağaranın ve pano ölçeğinde tutarlı figürlerin uzamsal/mekânsal organizasyonunun anlaşılmasını sağlamış olmasıdır (Clottes, 2003, ss. 8-9; Djindjian, 2009, s. 5; Sauvet, 1994).

Paleolitik sanattaki resimlerin bazılarının şamanlar ve onların koruyucu ruhlarıyla ilişkili olduğu yorumu Mircea Eliade, Andreas Lommel, Weston La Barre, Joan Halifax ve Noël Smith tarafından önerilmiştir. Paleolitik sanat ve Şamanizm ilişkisi özellikle James David Lewis-Williams tarafından ele alınmaktadır. Şamanizm, yaygın kullanılan bir kavram ve geniş bir uygulama çeşitliliği olmakla birlikte, evrensel benzerlikleri/ortaklıklar söz konusudur. Bu ortaklıkların ilki, iki veya daha fazla bir arada var olan farklı dünya ile ifade edilen karmaşık bir kozmos algısıdır. Farklı dünyalar arasında etkileşim söz konusudur, bir dünyada ortaya çıkan olayların sorumlusu, diğer dünyadan kaynaklanmaktadır. Eğer bir sorun var ise, örneğin uzun süre yağmur yağmamış ise bu dünya ve diğer dünya arasındaki gerekli ritim bozulmuştur, bunun yeniden inşası gerekmektedir. İkinci olarak farklı dünyalar arasında bozulan dengenin belirli kişiler

\footnotetext{
${ }^{13}$ A. Leroi-Gourhan'ın belgeleme sistematiği için bk. Institut National de l'Audiovisuel, http://www.ina.fr/video/CPF86605025/des-bisons-des-chevaux-et-des-singes-video.html.
} 
(Şamanlar) tarafindan düzeltilebileceği düşünülmektedir. Örneğin iki farklı dünya arasında denge yeniden kurulduğunda yağmur yağabilecektir. Üçüncüsü, özellik farklı dünyalar arasındaki temasın kuruluş biçimidir. İngilizlerin ruh-yardımcısı olarak adlandırdıkları şeyin, genellikle hayvan biçiminde olduğu ve şamana gelerek onunla özdeşleştiği ileri sürülmektedir. Şamanın ruhu kontrol etme seviyesi, şamanın gücünün göstergesi olarak yorumlanmaktadır. Temas kurmanın diğer bir biçimi ise şamanın kendi ruhunu diğer dünyaya göndererek ruhlarla tanışması ve yardım alması olabilir. Bunu trans yoluyla yaptığ 1 , bunun kimi zaman kalabalık törenlerle, kimi zaman ise yalnız yapıldığ belirtilmektedir. Diğer dünyanın belirli bir coğrafyası, oraya ulaşılması için ve geri dönüş için belirli tehlikelerin olduğu belirtilmektedir. Görüntünün, kendi içindeki gücü, dünyanın doğal ruhları ile iletişim kurmanın ayrıcalıklı bir yolu olabilir, özellikle de şaman inancı çerçevesinde (Clottes, 2003; 2004). Lewis-Williams, Şamanizmin iki veya çoklu dünya anlayışını, farklı dünyalar arasında bağlantı kurma sürecini Üst Paleolitik dönemde mağaralara girmek ve derinliklerinde ilerlemeyi, transa girerek öteki dünyayla bağlantı kurmaya benzetmektedir. Mağaralardaki yeraltı geçitlerini, galerileri öteki dünyaya ait şeyler olarak yorumlamakta ve bu alanlara geçişin somut ve sembolik olarak yeraltındaki öteki dünyaya geçişi ifade edebileceğine dikkat çekmektedir. Mağara duvarlarına yapılan resimlerde yer alan imgelerin öteki dünyada elde edilerek mağara duvarlarına sabitlendiğini ve bilinmeyen yolu "aydınlatan" öğeler olarak değerlendirilmesi gerektiğini ileri sürmektedir. Aslında imgelerle öteki dünyanın da kurulumunun yapıldığına dikkat çekmektedir. Bu yolla aslında, "halüsinasyonlar ya da ruhlar dünyası" geçiş alanı olarak mağaralarda somut olarak konumlandırılarak soyut olmaktan çıkarılıp ulaş1labilir biçimine çevrildiği düşünülmektedir (Lewis-Williams, 2019, ss. 196-198). Paillet'in (2015) tarihöncesi sanata yaklaşımı biraz daha insan merkezlidir diyebiliriz, o bunu şöyle ifade etmektedir; "Seçildikten sonra doğal ortamlarından çıkarılan hayvanlar, kültürel bir şekilde yeniden düzenlenir, yeniden ilişkilendirilir ve yeniden düşünülür. Böylece tarihöncesi sanatlar, gerçek dünya ile düşünce dünyasının temsilleri arasında gidip gelir”. Mithen (1999, ss. 184-187), Üst Paleolitik dönem sanatının sembolik anlamlarla doğrudan ilişkili olduğunu "tarihöncesi aklın kayıp mitolojik dünyasını" ifade ettiğini ileri sürmektedir. Sanat üretimi için üç bilişsel özelliğin var olması gerektiğine dikkat çekmektedir. Bunlar "görüntünün akılsal olarak algılanması, bilinçli iletişim ve anlam yükleme". Paleolitik sanatın yorumlanmasında son zamanlarda öne çıkan bakış açısı, bütün sanat kalıntılarını birlikte kapsayabilecek genel geçer bir açıklama yapılamayacağı yönündedir (Bracco ve Montoya, 2015, s. 84).

\section{Sonuç}

Tarihöncesinde sembolik düşünce veya sanat, insanın somutu-soyutlama; soyutusomutlama döngüsünü biçimlendirerek anlamlandırmasını, kendisini ve içinde yaşadığı 
toplumu devindirecek yeni bir hal yaratmasının yolu olarak, önceki varoluşundan kopuşu somutlayan kavramlardan biri olarak görülebilir. Homo cinsinin uzun tarihine bakıldığında sanatın kültürel örüntünün bileşeni olarak üretimi ve kullanımı görece yakın bir döneme denk gelmektedir. Bununla birlikte sembolik düşüncenin izleri olarak kabul edilen renkli pigmentlerin kullanımı, süslenme nesneleri olarak boncukların üretimi, ilk figürin heykel gibi betimlerin ortaya çıkışı, ölülerin bilinçli olarak gömülmesi, simetrik formlu aletlerin süreç içerisinde yavaş yavaş artışı söz konusudur.

Alt Paleolitik Dönem'den başlayarak, bir yanıyla sembolik anlamlar yüklenme potansiyeli taşıyan, diğer yanıyla insanların "estetik" yönlerinin dışavurumu olarak yorumlanabilecek, simetrik iki yüzeyli el baltaları, kırmızı pigment kullanımına dair kalıntılar, Homo cinsinin "temel gereksinim" kategorisinde değerlendirilmemiş ve sembolik düşüncenin izleri olarak yorumlanmıştır. Bu tür kalıntılarla dünyanın her yerinde karşılaşılmamaktadır. Ancak belirli niteliklerin en erken Homo türlerinde ortaya çıktığını gösteren uygulamalar olarak az sayıda örnek olsa da önem taşımaktadır.

Orta Paleolitik, Homo neanderthalensis'lerin etkin olduğu ve belirli bir süre sonra Homo sapiens'lerle karşılaştığı süreçtir. Orta Paleolitik Dönem'de Homo neanderthalensis ve Homo sapiens'lere ait ölü gömme uygulamalarının tarihlendiği dönemdir. Vialo (2009), ölünün gömülmesinin simgeselliğini, kolektif anlam inşa eden uygulama olarak değerlendirmektedir. Ölünün gömülmesi bir anlamda onun başka bir biçimde korunmas1, aynı zamanda duyguların örgütlenmesi, gelecek ve geçmiş arasında sürekliliği kurarak insanın kendisini tarihsel bir varlık olarak konumlandırmaya başlaması olarak da yorumlanabilir. Özellikle son yıllarda ki yeni keşifler ve yeni tekniklerle yapılan analizler, bu dönemde sembolik düşünceye dair kalıntıların çeşitlendiğini ve arttığını ortaya koymaktadır.

Üst Paleolitik, sembolik düşüncenin karmaşık biçimde yapılandırıldığına dair kayıtların tartışmasız biçimde artmasıyla öne çıkmaktadır. Sanatsal üretimin yoğunlaştığı ve teknik olarak karmaşıklaştığ süreç, dönem topluluklarının alet çantası ve alet üretim tekniklerindeki farklılaşmalardan kullanılan hammaddelerdeki çeşitlenmelere, bölgeler arasında sürekliliği sağlamaya yönelik araçların geliştirilmesine, birbiriyle ilişkili birçok öğenin eş zamanlı varlığı, toplulukların yaşam biçimlerinin ve dolayısıyla ürettikleri kültürün farklı biçimde yeniden örgütlenmesi olarak değerlendirilmektedir. Kültürel modernlik birçok şeyin bileşkesidir. Sembolik düşünce ve sanat, sıklıkla bir arada ele alınmakla birlikte biri diğerinin doğrudan önkoşulu veya sonucu değildir. Sembolün, bir anlamı iletme işlevi nedeniyle biçim ve anlam bağlantısı gerekmektedir. Sanat ise biraz daha farklı bir konumdadır. Avc1-derleyici konar-göçer grupların, farklı iklim bölgelerine, çeşitlenmiş coğrafyalara uyumlanmasında, farklı gruplarla karşılaşarak ilişkilenmede sembolik düşünce ve sanatın "birleştirici” olduğu ileri sürülebilir. Tarihöncesinde sanat günümüzde yüklenen "temel gereksinimler bittikten sonra ihtiyaç duyulan” bir şey olmaktan farklı olarak kültürel ayrımın kurucu öğesi gibi görünmektedir. 
Mağara sanatında işlenen konular ağırlıklı olarak hayvan betimlerine odaklanmakta hayvanlar-yaşadıkları doğal çevreden koparılmış olarak betimlenmektedir. Başka bir anlatımla, tarihöncesi sanatını icra edenler hayvanları doğal hallerinden soyutlayarak insana özgü sembolik bir dünyada yeniden vücuda getirmiş ve bir anlamda yaban hayatını sembolik de olsa ehlileştirmek için büyük adım atmış gibi görünmektedirler.

Arkeoloji yeni keşiflerin verileriyle kendini yeniden ve yeniden kuran dinamik bir bilim dalıdır. İspanya'da La Pasiega, Maltravieso ve Ardalas'taki açı̆̆a çıkarılan ve tarihleme sonuçlarına göre Homo neanderthalensisler tarafından üretildiği düşünülen mağara duvar resimleri ve yeni keşfedilen kalıntılarla eski hipotezler gözden geçirilerek yenilerine kap1 aralanmaktadır.

\section{Kaynakça}

Arsebük, G. (1995a). 'İnsan', 'Evrim', 'Alet'. Bilim ve teknik, 332, 18-24.

Arsebük, G. (1995b). Insan ve evrim, Ege Yayınları.

Atakuman, Ç. Karakoç, M. ve Gemici, H.C. (2019). Ölüyü gömmek ya da gömmemek: Paleolitik Çağ'da bedenin nesnelliği ve mekânsallı̆̆ı. Ç. Atakuman (Ed.) Arkeoloji'de Ritüel ve Toplum TAS 5, içinde (77-110). Ege Yayınları.

Azéma, M. (2006). La représentation du mouvement au Paléolithique Supérieur apport du comparatisme éthographique à l'interprétation de l'art pariétal. Bulletin de la Société préhistorique française, 103 (3), 479-505.

Azéma, M. (2015). De l'image à la narration graphique à l'Aurignacien. Aurignacian Genius 7. Art, technologie et société des premiers hommes modernes en Europe. https://doi.org/10.4000/palethnologie.850.

Balbín Behrmann, R. ve González J.J.A. (2009). Les colorants de l'art paléolithique dans les grottes et en plein air. L'anthropologie, 113, 559-601.

Barnard, A. (2012). Simgesel düşüncenin doğuşu. (M. Doğan, Çev.). Boğaziçi Üniversitesi Yayınları.

Bar-Yosef, O. (2006). Le cadre archéologique de la révolution du paléolithique supérieur. Diogène, 2(14), 3- 23. https://www.cairn.info/revue-diogene-2006-2-page-3.htm.

Bar-Yosef Mayer, D. E. ve Bosch, M. D. (2019). Special Issue: Early personal ornamentshumans' Earliest personal ornaments: An Introduction. PaleoAnthropology, 1923.

Bar-Yosef Mayer, D. E., Vandermeersch, B.ve Bar-Yosef, O. (2009). Shells and Ochre in Middle Paleolithic Qafzeh Cave, Israel: Indications for modern behavior. Journal of Human Evolution, 56(3), 307-314. 
Baykara, İ. ve Dinçer, B. (2018). Yontma taş alet çalışma metodolojisi. S. Ünlüsoy, C. Çakırlar, Ç. Çilingirlioğlu (Ed.). Arkeolojide Temel Yöntemler içinde (315- 352). Ege Yayınları.

Baykara, İ., Eren Kural, E., Açıkkol Yıldırım, A. ve Agras, M. K. (2021). Kuzey Levant'tan bir orta paleolitik dönem yerleşimi: Üçağızlı II mağarası buluntuları. Anadolu Araştırmaları, (24), 1-31. doi: 10.26650/anar.2021.24.972358.

Bogucki, P. (2013). Insan toplumunun kökenleri. (C. Atay, Çev). Kalkedon Yayınları.

Bracco, J. P. ve Montoyo, C. (2015). Le paléolithique supérieur en europe occidentale, de la construction des cadres classiques aux interrogations actuelles. J. Gagnepain (Ed.), La Préhistoire de l'Europe occidentale, un bilan des connaissances à l'aube du IIIe millénaire içinde (75-86).

Brot, J. (2012). L'utilisation des reliefs naturels dans l'art pariétal paléolithique. J Clottes (Ed.), L'art pléistocène dans le monde, numero spécial de préhistoire, Art et Sociétés, Bulletin de la Société Préhistorique Ariège-Pyrénées, LXV-LXVI, 7591.

Chalmin, E., Menu, M., ve Vignaud, C. (2003). Analysis of rock art painting and technology of Palaeolithic painters. Meas.Sci.Technol.14, 1590-1597.

Clottes, J. (2003). De 'l'art pour l'art' au chamanisme: l'interprétation de l'art préhistorique. Revue pour l'histoire du CNRS. http://journals.openedition.org/histoire-cnrs/553 https://doi.org/10.4000/histoire-cnrs.553.

Clottes, J. (2004). L'art rupestre dans le monde, https://www.clio.fr/BIBLIOTHEQUE/lart_rupestre_dans_le_monde.asp adresinden 16 Eylül 2020 tarihinde alınmıştır.

Condemi, S. ve Savatier, F. (2020). Homo sapiens. Sürüden devlete milyon yıllık serüven. (F. Ezici, Çev). Say Yayınları.

Davies, S. (2021). Behavioral modernity in retrospect. Topoi, 40, 221-232. https://doi.org/10.1007/s11245-019-09671-4.

d'Errico, F. ve Stringer, C.B. (2011). Evolution, revolution or saltation scenario for the emergence of modern cultures? Phil. Trans. R. Soc. B. 366, 1060-1069. doi:10.1098/rstb.2010.0340.

Djindjian, F. (2009). L'Art pariétal et l'art mobilier pour l'identification des territoires de peuplement dans le paléolithique supérieur européen: l'approche par les bestiaires" in symbolic spaces in prehistoric

Art Territories. F. Djindjian, O. Luiz (Ed.) Travels and Site Locations. Proceedings of the XV World Congress Vol. 40, Session C28, British Archaeological Reports (BAR) International Series (3-20) içinde, Archaeopress. 
Feruglio,V. ve Robert, E. (2015). L'art paléolithique autour d'André Leroi-Gourhan, les chemins de la recherche, vers une ethnologie préhistorique? P. Soulier (Ed.) André Leroi-Gourhan, "l'homme tout simplement" içinde (159-172). Editions de boccard.

Fritz C. ve Tosello G. (2015). From gesture to myth: artists' techniques on the walls of chauvet cave, R. White, R. Bourrillon (Ed.), Aurignacian Genius: Art, Technology and Society of the First Modern Humans in Europe, Proceedings of the International Symposium, April 08-10 2013, New York University, P@lethnology, 7, 280-314.

Fritz, C., Lennsen-Erz, T., Sauvet, G., Barbaza, M., López-Montalvo, E., Tosello, G. ve Azema, M. (2013). L'expression narrative dans les arts rupestres: Approches théoriques. Art rupestre. Des récits millénaires, Les dossiers de l'archéologie (358), 38-45.

Fuentes, O. (2015). Image de soi en préhistoire. Essais sur les enjeux de la représentation humaine pour les sociétés magdaléniennes. J. Brancier, C. Rémeaud ve T. Vallette (Ed.) Des vestiges aux sociétés:Regards croisés sur le passage des données archéologiques à la société sous-jacente içinde (171-192). Éditions de la sorbonne, doi 10.4000/books.psorbonne.4883.

Fuentes,O., Lepelé, J. ve Pinçon, G. (2019). Transferts méthodologiques 3D appliqués à l'étude de l'art paléolithique: une nouvelle dimension pour les relevés d'art préhistorique. In Situ. Revue des patrimonies, 39, 1-24 doi:10.4000/insitu.21510

Gamble, C. (2014). Arkeolojinin temelleri. (D. Kayıhan Çev.). Aktüelarkeoloji Yayınları.

Gaussein, P. (2017). L'art mobilier au paléolithique supérieur: complexité de l'identité et des réseaux de Cro Magnon. C. Gauvard (Ed.), Appartenances et pratiques des réseaux (36-49) içinde. Édition électronique du CTHS.

Garate-Maidagan, D. ve Moro-Abadia, O. (2012). Faut-il renoncer au « style I» de LeroiGourhan ? Une révision critique des débuts de l'art paléolithique. Bulletin de la Société Préhistorique Ariège-Pyrénées, LXViI, 67-79.

Groenen M. (2000). L'Image de la femme et de l'homme dans l'art du paleolithique européen. nouvelles perspectives de l'ecture. Annales d'Histoire de l'Art \& d'Archaeologie, XXII, 7- 41.

Groenen M. (2016). Le Statut de l'animal dans l'art pariétal du paléolithique supérieur. S. Peperstraete, (Ed.). Animal et religion) içinde (37-51. l'Université de bruxelles.

Harmand, S., Lewis, J. E., Feibel, C. S., Lepre, C. J., Prat, S., Lenoble, A., Boes, X., Quinn, R.L., Brenet, M., Arroyo, A., Taylor, N., Clement, S., Daver, G., Brugal, J.P., Leakey, L. Mortlock, R.A., Wright, J.D., Lokorodi, S., Kirwa, C., Kent, D.V. 
ve Roche, H. (2015). 3.3-million-year-old stone tools from Lomekwi 3, West Turkana, Kenya. Nature, 521, 310-328.

Hoffmann, D.L., Standish, C.D., García-Diez, M., Pettitt, P.B., Milton, J. A., Zilhão,J., Alcolea-González, J. J., Cantalejo-Duarte, P., Collado, H., Balbín, R.de, Lorblanchet, M. Ramos-Muñoz,J., Weniger, G.C. ve Pike, A. W. G. (2018). UTh dating of carbonate crusts reveals Neandertal origin of iberian cave art. Science $359,912-915$.

Karlin, C. ve Pelegrin, J. (1997). Technologie. A. Leroi-Gourhan (Ed.), Dictionnaire de la Prehistoire içinde (1074). Quadrige/Puf.

Kartal, M. (2015). Prehistorya (tarihöncesi) kavramı. Anadolu Prehistorya Araştırmaları Dergisi, 1, 145-162.

Kolankaya-Bostancı, N. (2012). Anadolu'da erken prehistorik dönem kırmızı aşı boyası kullanımı. Anatolia, 38, 29-51.

Kolankaya-Bostancı, N. (2019). Paleolitik Çağ'da ölüm ve sembolizm. A. M. Büyükkarakaya ve E. B. Aksoy (Ed.), Momento Mori Ölüm ve Ölüm Uygulamaları içinde (189-215). Ege Yayınları.

Lewin, R. (1998). Modern İnsanın Kökeni. (N. Özüaydın, Çev.). Tübitak Popüler Bilim Kitaplar1.

Le Tensorer, J.M. (2006). Les cultures acheuléennes et la question de l'emergence de la pensée symbolique chez homo erectus à partir des données relatives à la forme symétrique et harmonique des bifaces. Palevol 5, 127-135.

Langaney, A., Clottes, J., Guillaine, J. ve Simonnet, J. (2000). Insanın En Güzel Tarihi. (E. Çaykara, Çev.). Türkiye İş Bankası Yayınları.

Leroi-Gourhan, A. (1983). Les chasseurs de la préhistoire. A. M. Métailie.

Leroi-Gourhan, A (1990). Les religions de la prehistoire. Quadrige/Presses Universitaire de France.

Leroi-Gourhan, A. (1992). L'Art pariétal langage de la prehistoire. Jerome Millon.

Lewis-Williams, J.D. (2019). Mağaradaki zihin. (T. Esmer, Çev.). Yapı Kredi Yayınları.

Mar, D. (2021). Repartition geographique de l'art pariétal européen. https://solutreen.forumactif.org/t130-3-2-1-repartition-geographique-de-1-artparietal-europeen\#263 adresinden 12 Aralık 2021 tarihinde alınmıştır.

Ministère de la Culture, 2021. Art rupestre \& Grottes ornées. https://www.culture.gouv.fr/Thematiques/Archeologie/Le-Centre-national-deprehistoire/Art-rupestre-Grottes-ornees adresinden 25 Kasim 2021 tarihinde alınmıştır. 
Mithen, S. (1999). Aklın tarihöncesi. (İ, Kutluk, Çev.). Dost kitabevi.

Özbaşaran, M. (2019). Tarihöncesinin renk dünyasında kırmızı. Y. Ersoy, E. Koparal, G. Duru, Z. Aktüre (Ed.), Arkeoloji ve Göstergebilim, TAS 3 içinde (21-32). Ege yayınları.

Özdoğan, M. (2011). 50 Soruda arkeoloji (2.Baskı). Bilim ve Gelecek Kitaplı̆̆g.

Özdoğan, M. (2019). Hammaddeden ustalara, tarihöncesi arkeolojisinde malzeme. Arkeoloji ve Sanat Yayınları.

Özçelik, K. (2015). Türkiye'de üst paleolitik dönem: çeşitli yaklaşımlar ve problemler. Anadolu prehistorya araştırmaları dergisi, 1, 123-137.

Paillet, P. (2015). Art et comportements symboliques au paleolithiques: Quelques points de vue actuels. J. Gagnepain (Ed.), La préhistoire de l'europe occidentale, un bilan des connaissances à l'aube du IIIe millénaire içinde (87-101).

Pigeaud, R. (2017). L’Homme préhistorique et la mort. Palevol 5, 167-174.

Renfrew, C. ve Bahn, P. (2017). Arkeoloji, kuramlar, yöntemler ve uygulama. (G. Engin, Çev.). Homer Kitabevi.

Richard, N. (1993). De l'art ludique a l'art magique. Bulletin de la société préhistorique française, 90, 1-2, 60-68.

Raphaël, M. ve Schaefer, C. (1974). Sur la méthode d'interprétation de l'art paléolithique. Raison présente, 32, 35-63. https://doi.org/10.3406/raipr.1974.1706

Robert, É. (2012). Signes, parois, espaces. modalités d'expression dans le paléolithique supérieur ouest-européen. J. Clottes (Ed.), L'art pléistocène dans le monde $N^{\circ}$ spécial de Préhistoire, Art et Sociétés, Bulletin de la Société Préhistorique AriègePyrénées içinde (1941-1958).

Salmon, F., Ferrier, C., Lacanette D., Mindeguia, J.C., Leblanc J.C., Fritz, C., Sirieix, C. (2021). Numerical reconstruction of palaeolithic fires in the Chauvet-Pont d'Arc Cave (Ardèche, France). J Archaeol Method Theory 28, 604-616. https://doi.org/10.1007/s10816-020-09484-5.

Savaş Güleç, E. (2016). İnsanlığın ilk göçleri. paleolitik çağ insanında mobilite. Aktüel arkeoloji, kasım-aralık, 54, 28-45.

Sauvet, G. (1994). L'Art paleolithique, données et hypotheses. A. Fine, E. Perron, F. Sacco, (Ed.), Psychanalyse et Préhistoire içinde (167-182). Puf.

Sauvet, G. (2015). A la recherche du temps perdu. Methodes de datations en art prehistorique. l'exemple des sites aurignaciens. Aurignacian Genius: art, technologie et société des premiers hommes modernes en Europe, $\mathrm{P} @$ lethnologie, 210-225. 
Sauvet, G. (2019). The life world of hunter-gatherers and the concepts of territory. Quaternry International, 503, 191-199.

Sauvet, G. ve Wlodarczyk, A. (2001). L'Art parietal, miroir des societes paleolithiques. Zephyrus, 53-54; 217-240.

Steele, T.E., Álvarez-Fernández, E. ve Hallett-Desguez, E. (2019). Special Issue: Personal Ornaments in Early Prehistory. A Review of Shells as Personal Ornamentation During the African Middle Stone Age. PaleoAnthropology, 24-51.

Taborin, Y. (1998). L'art des premières parures. F.Sacco ve G. Sauvet (Ed.). Le propre de l'homme Psychanalyse et préhistoire (123-150) içinde. Delachaux et niestlé.

Taşkıran, H. (2012). Prehistorya; tarihöncesi arkeolojisi. N. Kazancı ve A. Gürbüz (Ed.) Kuvaterner Bilimi içinde (171-193). Ankara üniversitesi yayınları.

Théry-Parisot, I. Thiébault, S., Delannoy, J. J., Ferrier, C., Feruglio, V., Fritz, C., Gely, B., Guibert, P., Monney, J., Tosello, G., Clottes, J. ve Geneste, J.M. (2018). Illuminating the cave, drawing in black: wood charcoal analysis at chauvet-pont d'arc. Antiquity, 92, 362, 320-333.

Tillier, A.M. (2009). L'homme et la Mort. L'émergence du geste funérairedurant la préhistoire. CNRS Edition.

Valladas, H., Tisnérat-Laborde; N., Cacher, H., Kaltnecker, E., Arnold, M., Oberlin, C. ve Evin, J. (2005). Bilan des datations carbone 14 effectuées sur des charbons de bois de la grotte chauvet. Bulletin de la société préhistorique française, 102(1) 109-113. https://doi.org/10.3406/bspf.2005.13342

Vialou, D. (2009). L'Image du sens, en préhistoire. L'anthropologie, 113, 464-477.

White, R ve ark., (2019). Still no archaeological evidence that Neanderthals created Iberian cave art, Journal of Human Evolution, https://doi.org/10.1016/j.jhevol.2019.102640

Yalçınkaya, I. (1978). Taş devirleri sanatında teknik ve stil. Ankara üniversitesi, dil ve tarih coğrafya fakültesi dergisi, 29, 67-82. 